Boletín de la Sociedad Geológica Mexicana

VOLUMEN 61, NÚM. 2, 2009, P. 245-265

\title{
Protoglobicephala mexicana, a new genus and species of Pliocene fossil dolphin (Cetacea; Odontoceti; Delphinidae) from the Gulf of California, Mexico
}

\author{
Gabriel Aguirre-Fernández ${ }^{1, *}$, Lawrence G. Barnes², Francisco J. Aranda-Manteca ${ }^{1}$, Jorge R. \\ Fernández-Rivera ${ }^{3}$ \\ ${ }^{1}$ Laboratorio de Paleontología, Facultad de Ciencias Marinas, Universidad Autónoma de Baja California, Ensenada, Baja California, \\ México, 22800. \\ ${ }^{2}$ Department of Vertebrate Paleontology, Natural History Museum of Los Angeles County, Los Angeles, California, U.S.A., 90007. \\ ${ }^{3}$ Universidad Autónoma de Baja California Sur, La Paz, Baja California Sur, México. 23080. \\ *gaboaguirre@gmail.com
}

\begin{abstract}
The Delphinidae is the most diverse living family of odontocete cetaceans and includes modern oceanic dolphins and their fossil relatives. In contrast, the world-wide fossil record of this family is sparse when compared to that of several other cetacean groups, and relatively few extinct delphinids have been formally named. Most of the known fossil Delphinidae are of Pliocene age, and most of these are from Europe. We describe a new genus and new species of extinct Delphinidae, Protoglobicephala mexicana, based on a cranium of Pliocene age, between approximately 2 and 3 million years old, from Isla San Jose in the Gulf of California, Baja California Sur, Mexico. This species shares with Recent species of Globicephala wide exposures of the premaxillae on the dorsal surface of the rostrum and rugose areas on the distal ends of the premaxillae. Like other Globicephalinae members, it is a relatively large animal and has a wide cranium, short and broad rostrum, and relatively few teeth that are of relatively large size. It also shares some similarities with the generalized delphinine delphinid Tursiops. These similarities and the geochronologically relatively young occurrence of this new species reinforce previous notions that the present taxonomic diversity of the family Delphinidae is the result of rapid evolutionary diversification since Miocene time, or within approximately the past five million years. The ability of living species of Delphinidae in different genera, and in different nominal subfamilies, to mate and to produce viable hybrid offspring, offers additional support for the idea of rapid and recent evolutionary diversification of this family.
\end{abstract}

Keywords: Protoglobicephala mexicana, new genus and new species, Delphinidae, Pliocene, Gulf of California.

\section{Resumen}

Delphinidae es la familia más diversa de cetáceos odontocetos e incluye a los delfines oceánicos actuales y especies fósiles relacionadas. En contraste, el registro fósil mundial de esta familia es escaso comparado con el de otros grupos de cetáceos y pocas especies extintas se han nombrado formalmente. Gran parte del registro fósil de esta familia pertenece al Plioceno, la mayoría ha sido nombrado a partir de ejemplares encontrados en Europa. Se describe un nuevo género y nueva especie de un Delphinidae extinto, Protoglobicephala mexicana, basándose en un cráneo de edad Plioceno, de aproximadamente dos a tres millones de años de antigüedad, descubierto en Isla San José en el Golfo de California, Baja California Sur, México. Esta especie comparte con las especies actuales del género Globicephala la gran anchura de las premaxilas en la superficie dorsal del rostro y la presencia de áreas rugosas en los extremos distales de las premaxilas. Al igual que otros miembros de la subfamilia Globicephalinae, es un animal relativamente grande, que posee un cráneo ancho, un rostro corto y ancho y pocos dientes, los cuales son relativamente grandes. El ejemplar comparte 
algunas otras características con Tursiops, un Delphininae generalizado. Estas similitudes, junto con la relativamente reciente ocurrencia geocronológica de esta nueva especie, refuerzan hipótesis previas que interpretan la diversidad taxonómica actual de la familia Delphinidae como el resultado de una rápida diversificación evolutiva que tuvo lugar en el Mioceno, o aproximadamente durante los últimos cinco millones de años. La habilidad de cruza entre géneros diferentes y hasta miembros de subfamilias diferentes y la producción de híbridos fértiles en algunas especies vivientes de Delphinidae ofrece un apoyo adicional a la idea de una reciente y rápida diversificación evolutiva de esta familia.

Palabras clave: Protoglobicephala mexicana, nuevo género y especie, Delphinidae, Plioceno, Golfo de California.

\section{Introduction}

Members of the Delphinidae are the most diverse extant family-level group of cetaceans (Rice, 1998), with approximately 36 recognized living species. The evolutionary relationships of the group have been the subject of much discussion, including such earlier essays as Fraser and Purves (1960), Kasuya (1973), and Mead (1975), morphologic studies of the family by Muizon (1988) and Barnes (1990), and more recently-developed molecular research by LeDuc et al. (1999) and Pichler et al. (2001). None of the papers cited above has established a definitive classification of the fossil and living members of the family Delphinidae, but all of them suggested the need for more studies emphasizing basic taxonomy of both fossil and living species.

The odontocete fauna from Pliocene age sediments of the Gulf of California is similar to the Recent fauna (Aguirre-Fernández, 2009), represented by mainly modern Delphinoidea of the family Delphinidae. This contrasts with a notable dominance of the families Phocoenidae and Monodontidae during the Late Miocene, and of the extinct Kentriodontidae during the Middle Miocene (Barnes, 2002). The change in the odontocete fauna during the Pliocene is a notable phenomenon that has been observed globally (Barnes, 2002). On the global scale, Fordyce and Barnes (1994) suggested that the general cooling that started in Middle Miocene time was one influence causing this.

A local change was proposed by Bianucci (2005): the extinction of the Mediterranean cetacean fauna related to the closing off and desiccation of the Mediterranean during the Late Miocene Messinian crisis, and its subsequent repopulation by new taxa.

The geologic evolution of the Proto-Gulf of California is still very much in debate (see Thomas and Barnes, 1993; Deméré, 1993; Helenes and Carreño, 1999; Martín-Barajas, 2000; Riddle et al., 2000; Ledesma-Vázquez, 2002). Studies of the local composition of fossil Delphinidae from the Gulf of California could contribute to understanding the global and local background for the evolution of the Delphinidae, as well as to understanding some aspects of the geological evolution of the Gulf of California (Aranda-Manteca et al., 2008, 2009).

The purpose of this paper is to describe a new genus and new species of fossil Delphinidae of Pliocene age from the Gulf of California, and to present a phylogenetic analysis that will place it in evolutionary perspective. This work is the result of a cruise of the ship "Don José" of La Paz, Baja California Sur, Mexico, as part of the Members Travel Program of the Natural History Museum of Los Angeles County; subsequent collecting by Jorge Fernández-Rivera; a Bachelor's thesis (Aguirre-Fernández, 2006) which was supervised by Jorge Urbán-Ramírez, Luis A. Herrera-Gil, and Lawrence G. Barnes; and a Master's thesis (AguirreFernández, 2009) that was supervised by Francisco J. Aranda-Manteca, Lawrence G. Barnes, and Miguel A. Téllez-Duarte.

\section{Study Area}

The fossil dolphin described in the present paper was collected from a 300-meter-thick deposit of Late Pliocene age bedded sandstones, 3.6-2.5 Ma in age (Umhoefer et al., 2007) at Punta Colorada, San Jose Island, in the Gulf of California, Mexico. The deposit is in one of two transtensional sedimentary sub-basins located on the island (Figures 1 and 2A).

The layer where the fossil of the new dolphin was found is referred to as the lower bedded shelly sandstone (identified as "bs" in Umhoefer et al., 2007). It underlies the La Gata Mudstone, which has been dated at 2.4 to $2.2 \mathrm{Ma}$ on the basis of planktonic foraminiferans. It also overlies a tuffaceous sandstone, which has been dated at $3.6 \pm 0.5 \mathrm{Ma}$ using ${ }^{40} \mathrm{Ar} /{ }^{39} \mathrm{Ar}$ in plagioclase feldspar crystals (Umhoefer et al., 2007). The bs stratigraphic unit is a rich bioclastic sandstone with abundant pectinids, including some that have been identified by Ruiz-Geraldo (2005) as Nodipecten subnodosus Sowerby, 1836. Fossils of echinoderms, barnacles, oysters, shark teeth, turtles, and odontocete and mysticete whales have also been found in this same unit (Aguirre-Fernández, 2006).

According to the interpretations of Umhoefer et al. (2007), the sedimentary facies that yielded the fossil dolphin represents an inner shelf setting, with variable energy conditions. The shell-rich beds could have been formed by storms. 


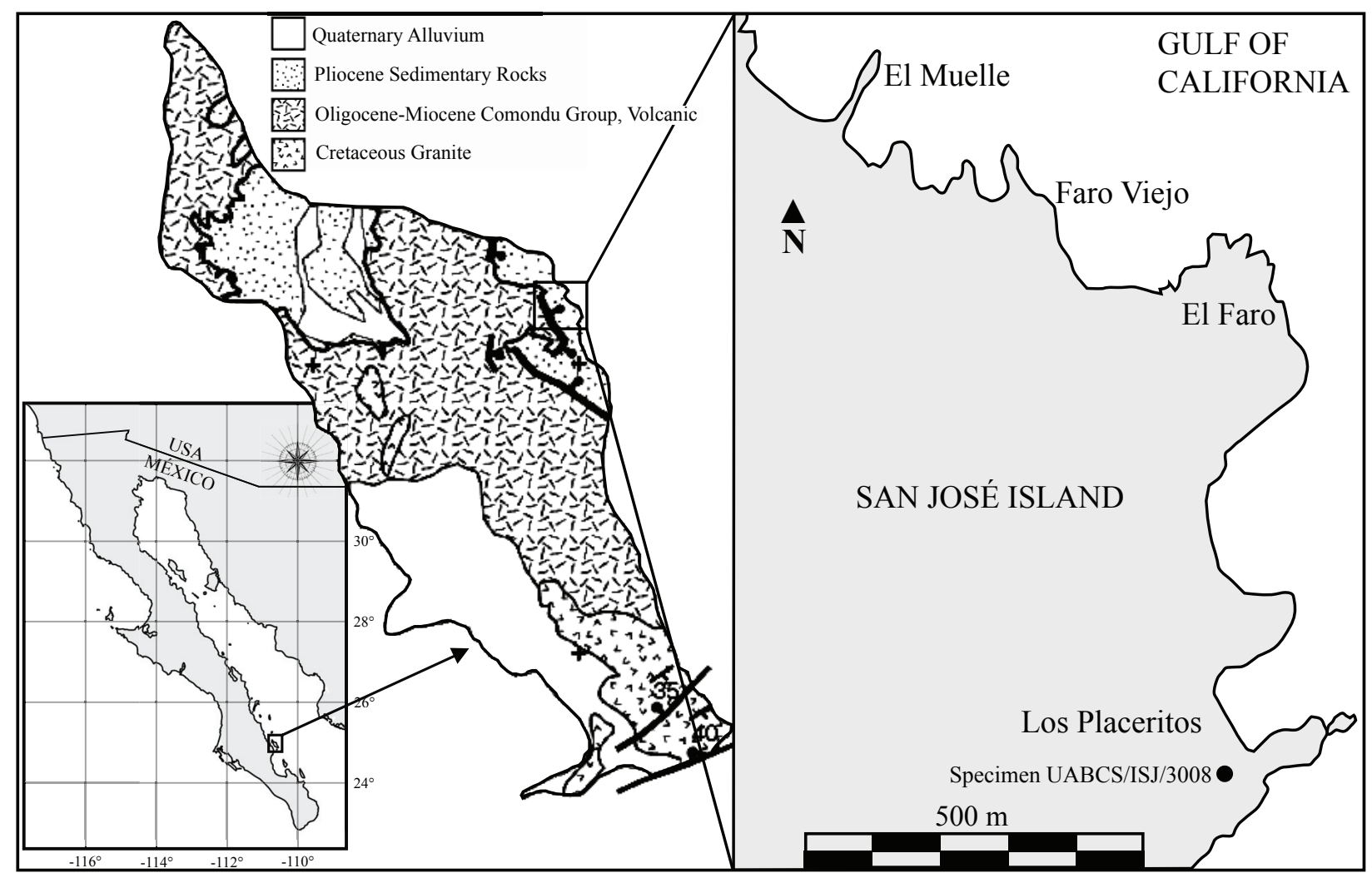

Figure 1. Maps showing the type locality of Protoglobicephala mexicana, new genus and new species, holotype specimen UABCS/ISJ/3008, near Los Placeritos Beach, San José Island, Gulf of California, Baja California Sur, Mexico; geological information is from Umhoefer et al. (2007), base maps are from Google Earth and NASA Visible Earth images.

\section{Methods}

\subsection{Acronyms}

CNMA Colección Nacional de Mamíferos, Instituto de Biología, Universidad Nacional Autónoma de México, Mexico City, Mexico.

INAH Instituto Nacional de Antropología e Historia, Centro Baja California Sur, Mexico.

LACM Department of Vertebrate Paleontology, Natural History Museum of Los Angeles County, Los Angeles, California, U.S.A.

UABC Facultad de Ciencias Marinas, Universidad Autónoma de Baja California, Ensenada, Baja California, Mexico.

UABCS Museo de Historia Natural, Universidad Autónoma de Baja California Sur, La Paz, Baja California Sur, Mexico.

\subsection{Anatomical measurements and characteristics}

The anatomical measurements taken from the holotype specimen and from some of the compared species follow the methods of Perrin (1975); the measurements of the ear bones follow Bianucci (1996). Some measurements were made directly from specimens in the collections of LACM and CNMA.

In some cases, the data (measurements and qualitative information) for some species was taken from the literature: for Delphinus delphis from Heyning and Perrin (1991); for Globicephala macrorhynchus from Miyasaki and Amano (1994) and Bianucci (2005); for Kentriodon pernix from Kellogg (1927); for Orcinus orca from Tomilin (1957) and Aguirre-Fernández (2006); for Peponocephala electra from Bianucci (2005); for Pseudorca crassidens from Bianucci (2005); for Stenella attenuata from Perrin et al. (1987); and for Tursiops truncatus from Aguirre-Fernández (2006).

\subsection{Phylogenetic analysis}

A computer-assisted phylogenetic analysis was performed using PAUP* version 4.0 b10 (Swofford, 2002). The matrix contained 21 cranial characters of the holotype specimen (UABCS ISJ/3008) of Protoglobicephala mexicana, new genus and new species, and the ten odontocete species mentioned in table 1 (all of which are members of the family Delphinidae, except for the 


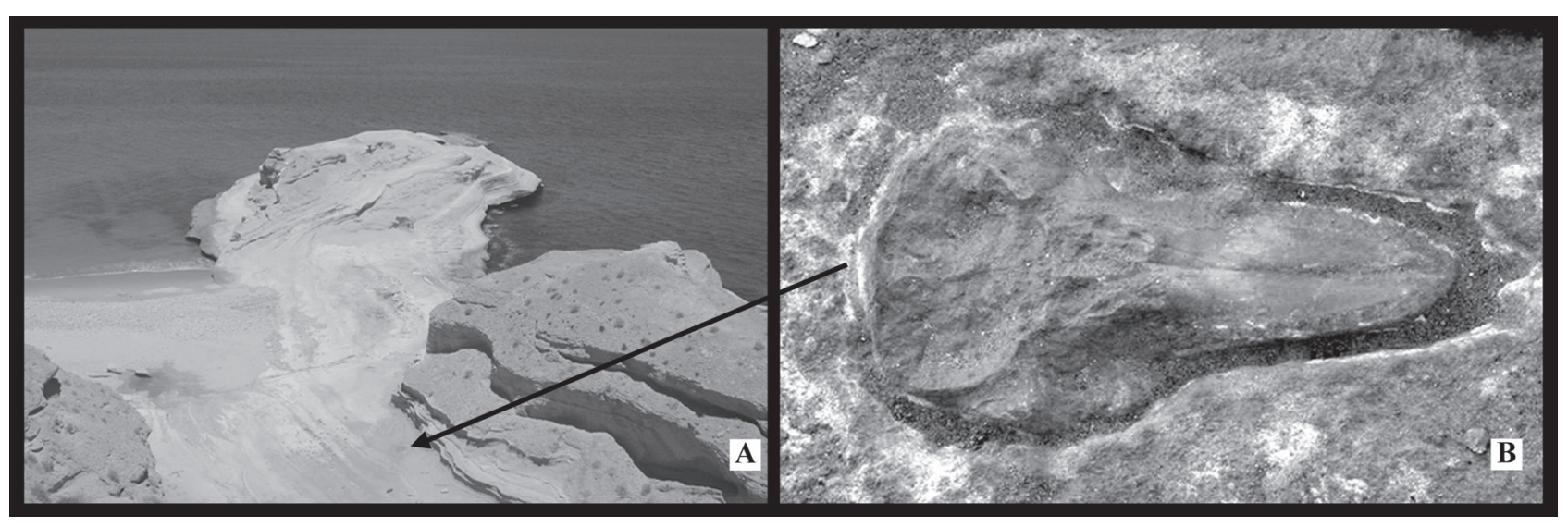

Figure 2. The collecting site of Protoglobicephala mexicana, new genus and new species, holotype specimen UABCS/ISJ/3008; A, view eastward from above Los Placeritos Beach, Isla San José, Baja California Sur, Mexico; arrow points to site of discovery of UABCS/ISJ/3008; B, cranium of holotype specimen, UABCS/ISJ/3008, exposed in ventral view in rock, rostrum to the right, with borders of specimen partly excavated.

extinct kentriodontid delphinoid, Kentriodon pernix). The characters were coded as binary or multistate (Table 1).

The characters and character states used in this analysis were partially taken from previous works: Muizon (1988), Barnes (1990), and Bianucci (2001, 2005). Some of the characters or character states previously considered by other authors have been reformulated, and some characters are proposed here for the first time (Table 2).

The maximum-parsimony phylogenetic analysis was performed using the branch and bound search option of PAUP, considering all the characters as ordered (Wagner method) and unweighted. The species Kentriodon pernix was established a priori as the outgroup, assuming its characters to be plesiomorphic (see Barnes et al., 2008). The character-state optimization used was the delayed transformation option (deltran).

\section{Material}

\subsection{Fossil material}

The examined fossil bones were recovered in a single block of sandstone measuring about $60 \times 45$ centimeters, and consist of a partial skull (lacking the basicranium and ventral parts of the pterygoid sinuses) (Figure 2B), two teeth, an incomplete right petrosal, the right tympanic bulla, and one of the middle ear bones, the incus. This material is catalogued as UABCS/ISJ/3008, and housed in UABCS. Replicas of the skull have been deposited in INAH, $\mathrm{LACM}, \mathrm{UABCS}, \mathrm{UABC}$, and one was installed at the site of discovery at Isla San José, Baja California Sur, Mexico.

\subsection{Material for phylogenetic analysis}

For the phylogenetic analysis, we compared the holotype specimen (UABCS ISJ/3008) of Protoglobicephala mexicana, new genus and new species, with a fossil kentriodontid delphinoid, Kentriodon pernix Kellogg, 1927; and with the following Recent species of the family Delphinidae: Stenella attenuata (Gray, 1846); Stenella frontalis (Cuvier, 1829); Tursiops truncatus (Montagu, 1821); Delphinus delphis Linnaeus, 1758; Globicephala macrorhynchus Gray, 1846; Orcinus orca (Linnaeus, 1758); Peponocephala electra (Gray, 1846) as reported by Nishiwaki and Norris (1966); and Pseudorca crassidens (Owen, 1846).

\section{Results}

\subsection{Systematic Paleontology}

Order Cetacea Brisson, 1762

Suborder Odontoceti (Flower, 1865) Flower, 1867

Superfamily Delphinoidea (Gray, 1821) Flower, 1865

Family Delphinidae Gray, 1821

Delphinidae Gray, 1821.

Delphinusidae Lesson, 1842. An incorrect subsequent spelling of Delphinidae.

Orcadina Gray, 1846. As a section of Delphinidae, "Implicitly based on Orca Gray, 1846 [=Orcinus], which is preoccupied by Orca Wagler, 1830 [=Hyperoodon]" (Rice, 1998). Orcadina is an unavailable name because its type genus is a junior homonym (ICZN Code, $4^{\text {th }}$ edition, 1999, Article 39; see Rice, 1998).

Globiocephalidae Gray, 1850. A family, having as its type genus Globiocephalus Gray, 1843, which is an incorrect subsequent spelling of Globicephala (see Rice, 1998).

Grampidae Gray, 1871. A family, having as its type genus Grampus Gray, 1828 (see Rice, 1998).

Orcadae Gray, 1871. A family, having as its type genus Orca Gray, 1846 [=Orcinus], but which is an unavailable name because its type genus is a junior homonym (ICZN Code, 4th edition, 1999, Article 39; see Rice, 1998).

Holoodontidae Brandt, 1873. A family that included 
Table 1. Matrix of coding of characters that were used in the analysis of relationships of ten taxa of Cetacea, of which nine are Delphinidae, and which when analyzed yielded the trees shown in Figures 8 and 9. The 21 characters are listed and explained in previous text. Character codings are: [0] postulated plesiomorphic condition of a character; [1] postulated apomorphic condition of a character; [2] alternative apomorphic condition of a character; and [?] condition of the character is not preserved on the holotype specimen.

\begin{tabular}{lccccccccccccccccccccc}
\hline Taxa & $\mathbf{1}$ & $\mathbf{2}$ & $\mathbf{3}$ & $\mathbf{4}$ & $\mathbf{5}$ & $\mathbf{6}$ & $\mathbf{7}$ & $\mathbf{8}$ & $\mathbf{9}$ & $\mathbf{1 0}$ & $\mathbf{1 1}$ & $\mathbf{1 2}$ & $\mathbf{1 3}$ & $\mathbf{1 4}$ & $\mathbf{1 5}$ & $\mathbf{1 6}$ & $\mathbf{1 7}$ & $\mathbf{1 8}$ & $\mathbf{1 9}$ & $\mathbf{2 0}$ & $\mathbf{2 1}$ \\
\hline Kentriodon pernix & 0 & 0 & 0 & 0 & 0 & 0 & 0 & 0 & 0 & 0 & 0 & 0 & 0 & 0 & 0 & 0 & 0 & 0 & 0 & 0 & 0 \\
Orcinus orca & 2 & 1 & 1 & 1 & 1 & 2 & 0 & 1 & 1 & 1 & 1 & 1 & 1 & 2 & 1 & 0 & 0 & 0 & 0 & 0 & 0 \\
Peponocephala electra & 2 & 1 & 1 & 1 & 1 & 1 & 0 & 0 & 1 & 1 & 1 & 1 & 1 & 1 & 0 & 1 & 1 & 0 & 0 & 0 & 0 \\
Globicephala macrorhynchus & 2 & 1 & 1 & 2 & 1 & 2 & 1 & 1 & 1 & 1 & 1 & 1 & 1 & 2 & 1 & 0 & 0 & 0 & 0 & 0 & 0 \\
Pseudorca crassidens & 2 & 1 & 1 & 2 & 1 & 2 & 0 & 1 & 1 & 1 & 1 & 1 & 1 & 2 & 1 & 0 & 0 & 0 & 0 & 0 & 0 \\
Tursiops truncatus & 1 & 0 & 0 & 1 & 1 & 1 & 0 & 0 & 0 & 1 & 1 & 1 & 1 & 1 & 1 & 0 & 0 & 1 & 1 & 1 & 1 \\
Delphinus delphis & 0 & 0 & 0 & 0 & 1 & 1 & 0 & 0 & 0 & 0 & 1 & 1 & 1 & 0 & 0 & 1 & 1 & 1 & 1 & 1 & 1 \\
Stenella frontalis & 1 & 0 & 0 & 0 & 1 & 1 & 0 & 0 & 0 & 1 & 1 & 1 & 1 & 0 & 0 & 1 & 1 & 1 & 1 & 1 & 1 \\
Stenella attenuata & 0 & 0 & 0 & 0 & 1 & 1 & 0 & 0 & 0 & 0 & 1 & 1 & 1 & 0 & 0 & 1 & 1 & 1 & 1 & 1 & 1 \\
Protoglobicephala mexicana & 1 & 1 & 0 & 2 & 1 & 2 & 1 & 1 & 1 & 1 & 1 & 1 & 1 & 2 & 1 & 0 & 0 & $?$ & $?$ & $?$ & $?$ \\
\hline
\end{tabular}

Table 2. Definitions of morphologic characters used in the phylogenetic analysis. The following characters are those that we found to be useful among the Delphinoidea, some with other sources indicated. The numbers of the characters are the same that appear in the matrix (Table 1). Character states are: [0] indicates a plesiomorphic character state, [1] indicates an apomorphic character state, and [2] indicates an alternative apomorphic character state; CBL equals condylobasal length. Kentriodon pernix Kellogg, 1927, influenced some of our choices of the character polarities (Barnes et al., 2008).

\section{Rostrum}

1. Rostrum length: (0) very long ( $>60 \% \mathrm{CBL})$; (1) long (60-55\% CBL); (2) short ( $<55 \% \mathrm{CBL}$ ) (see Bianucci, 2005$)$.

2. Premaxillae at the anterior end of the rostrum: (0) convergent; (1) with parallel or divergent lateral margins (modified from Bianucci, 2005).

3. Dorsal surface of the premaxilla in the anterior portion of rostrum is: (0) convex and elevated; (1) nearly flat (modified from Bianucci, 2005).

4. Premaxillary width at mid-rostrum as a function of CBL is: (0) narrow $(<10 \%)$; (1) medium $(10-15 \%)$; (2) wide $(>15 \%)$.

5. Lateral margin of the rostrum is: (0) concave; (1) convex (Bianucci, 2001).

6. Rostrum width at mid-length is: $(0)$ very narrow ( $<10 \% \mathrm{CBL})$; (1) narrow $(10-20 \% \mathrm{CBL})$; (2) wide $(>20 \% \mathrm{CBL})$ (modified from Barnes, 1990$)$.

7. Rugosities near the anterior end of the dorsal surface of the premaxilla are: (0) absent; (1) present.

Neurocranium

8. Antorbital process is: (0) tapered anteriorly and relatively narrow; (1) globose anteriorly and robust (Bianucci, 2005).

9. Antorbital notch is deep and wide: (0) no; (1) yes (Bianucci, 2005).

10. Zygomatic width as a percentage of CBL: $(0)<45 \%$; (1) $\geq 45 \%$ (modified from Barnes, 1990).

11. Cranial vertex skewed asymmetrically to the left side: (0) absent; (1) present (Barnes, 1990; Bianucci, 2005).

12. Posterior end of left premaxilla always narrower and shorter than right premaxilla and retracted anteriorly away from the anterolateral corner of the left nasal bone: (0) absent; (1) present (Barnes, 1990; Bianucci, 2005).

13. Development of a mesethmoid plate over-spreading the posterior surface of the narial fossae and a consequent anteroposterior compression of the nasal bones: (0) absent; (1) present (Muizon, 1988; Barnes, 1990; Bianucci, 2005).

Teeth

14. Number of teeth in each upper alveolar tooth row: (0)>28; (1) 28-20; (2)<20 (modified from Bianucci, 2005).

15. Transverse diameter of dental alveolus at mid-rostrum: (0) small ( $<2 \% \mathrm{CBL})$; (1) large $(\geq 2 \%)$.

16. Increase in number of teeth: (0) absent; (1) present (Barnes, 1990; Bianucci, 1996).

17. Decrease in size of teeth: (0) absent; (1) present (Bianucci, 2005).

Ventral sinus

18. Enlargement of anterior sinus of the pterygoid sinus on the posterior end of palate: (0) no; (1) yes (Muizon, 1988; Bianucci, 1996).

19. Widening of apices of preorbital and postorbital lobes of the pterygoid sinus, with a tendency to fuse together and to envelop the optic nerve in a canal: (0) absent; (1) present (Muizon 1988; Bianucci 2005).

20. Middle sinus apex lobulated and irregular: (0) absent; (1) present (Muizon, 1988; Bianucci, 2005).

21. Supplementary expansion of pterygoid sinus in the sphenoidal region: (0) no (1) yes (Muizon, 1988; Bianucci, 2005).

Platanistinae, Phocaeninae, Delphininae, and Orcinae; but which is "not available because it is not based on the stem of a generic name" (Rice, 1998).

Hemisyntrachelidae Slijper, 1936. A family, having as its type genus Hemisyntrachelus Brandt, 1873; to include only Hemisyntrachelus and Lophocetus.

Orcaellidae Nishiwaki, 1963. A family, having as its type genus Orcaella Gray, 1866.
Globicephalidae Nishiwaki, 1963. Justified emendation of Globiocephalidae Gray, 1850 (see Rice, 1998).

Globidelphinidae Nishiwaki, 1963. A family to include only Grampidelpis Iredale and Troughton, 1933 [=Grampus Gray, 1828]; but which is not an available name "because it is not based on the stem of a generic name" (Rice, 1998).

Grampidae. Nishiwaki, 1963. 
Orcaelidae Nishiwaki, 1972. Incorrect subsequent spelling of Orcaellidae Nishiwaki, 1963 (see Rice, 1998).

Subfamily Globicephalinae (Gray, 1850) Nishiwaki, 1963 Orcadina Gray, 1846. As a section of Delphinidae, "Implicitly based on Orca Gray, 1846 [=Orcinus], which is preoccupied by Orca Wagler, 1830 [=Hyperoodon]." (Rice, 1998), but which is an unavailable name because its type genus is a junior homonym (ICZN Code, Article 39; see Rice, 1998).

Orcadina. Gray, $1850 ; 1868$. As a tribe of Delphinidae to include Orcinus orca and Feresa intermedia (Rice, 1998).

Orcini Wagner, 1846. Having as its type genus Orca Gray, 1846 [=Orcinus], but which is an unavailable name because its type genus is a junior homonym (ICZN Code, Article 39; see Rice, 1998).

Globiocephalidae Gray, 1850. A family, having as its type genus Globiocephalus Gray, 1843, which is an incorrect subsequent spelling of Globicephala (see Rice, 1998).

Globiocephalidae Gray, 1866.

Pseudorcaina Gray, 1871. Having as its type genus Pseudorca Reinhardt, 1862 (see Rice, 1998).

Grampidae Gray, 1871. A family, having as its type genus Grampus Gray, 1828 (see Rice, 1998).

Orcadae Gray, 1871. A family, having as its type genus Orca Gray, 1846 [=Orcinus], but which is an unavailable name because its type genus is a junior homonym (ICZN Code, Article 39; see Rice, 1998).

Globicipites Winge, 1918, 1921.

Orcinae Fraser and Purves, 1960. As a subfamily of Delphinidae. Fraser and Purves (1960) indicate its type genus as being Orcinus, which would make it an incorrect original spelling. Fraser and Purves (1960) indicate its type genus as being Orca, [=Orcinus], but which is an unavailable name because its type genus is a junior homonym (ICZN Code, Article 39; see Rice, 1998). In either case this proposed subfamily name is not correct.

Orcaellidae Nishiwaki, 1963. A family, having as its type genus Orcaella Gray, 1866.

Globicephalidae Nishiwaki, 1963. Justified emendation of Globiocephalidae Gray, 1850 (see Rice, 1998).

Globidelphinidae Nishiwaki, 1963. A family to include only Grampidelpis Iredale and Troughton, 1933 [=Grampus Gray, 1828]; but not an available name "because it is not based on the stem of a generic name" (Rice, 1998).

Orcininae Rice, 1967. A subfamily of Delphinidae, [=Orcinae Fraser and Purves, 1960]; a "justified emendation, in accordance with ICZN Code, Articles 29, 32(c)(iii), and 32(d)" (see Rice, 1998).

Orcaelidae Nishiwaki, 1972. Incorrect subsequent spelling of Orcaellidae Nishiwaki, 1963 (see Rice, 1998).

Included genera: Globicephala Lesson, 1828; Pseudorca Reinhardt, 1862; Protoglobicephala, new genus; Orcinus
Fitzinger, 1860; probably also including Grampus Gray, 1828; Feresa Gray, 1870; and Peponocephala Nishiwaki and Norris, 1966; and possibly also including Orcaella Gray, 1866; and Hemisyntrachelus Brandt, 1873.

Comment. Some classifications of Cetacea recognize a delphinid subfamily Globicephalinae, and some also recognize a subfamily Orcinae (Fraser and Purves, 1960) or its emended form, Orcininae (Rice, 1967).

For example, Simpson (1945) did not list subfamilies within the Delphinidae. Evans (1987) included within the subfamily Globicephalinae the genera Peponocephala, Feresa, Pseudorca, Orcinus, Grampus, and Globicephala, but did not include Orcaella. Bonner (1989) did not include subfamilies in his classification, but implied such a grouping when he listed the same genera, in the same sequence, as Evans did (1987) at the end of the list of genera of the family Delphinidae. Similarly, Rice (1998) did not use subfamilies within the Delphinidae, but he did cluster at the end of his list of delphinid genera the broad-headed members that constituted the subfamily Globicephalinae of Evans (1987). Perrin (1989) included within the subfamily Globicephalinae the genera Peponocephala, Feresa, Pseudorca, Orcinus, and Globicephala, and within a separate delphinid subfamily, the Orcaellinae, the genus Orcaella. The classification of LeDuc (2002) differed from that of Perrin by having Orcinus in the subfamily Orcaellinae, as well as Orcaella. Slijper (1936) named the family Hemisyntrachelidae, to which he assigned the genus Hemisyntrachelus, which included fossil species that had been previously assigned to Tursiops, as well as Lophocetus, a fossil genus that is now assigned to the extinct delphinoid family Kentriodontidae (Barnes, 1978). We do not recognize a separate family Hemisyntrachelidae.

We do not here intend to resolve these issues, or to define the full contents of the subfamily Globicephalinae. By tautonymy, the subfamily Globicephalinae unequivocally includes the type genus, Globicephala. To this subfamily we assign Protoglobicephala, new genus, described herein. We also tentatively accept the contents of the Globicephalinae as it was used by Evans (1987), and make comparisons with the genera Hemisyntrachelus, Feresa, Grampus, Orcinus, Pseudorca, Orcaella, and Peponocephala, because these all include relatively broad-headed species, and because they do cluster as a natural grouping in our cladistic analysis.

\section{Genus Protoglobicephala, new genus}

“...probable nuevo genero y especie...”. AguirreFernández et al., 2004.

"...a probable new genus and species of delphinid...". Aguirre-Fernández et al., 2005.

“...Delphinidae de Isla San José...”. Aguirre-Fernández, 2006.

“...two new genera and species of Pliocene dolphins...". Aguirre-Fernández et al., 2008a.

"Un ejemplar posee caracteres intermedios entre los géneros actuales Tursiops y Globicephala;...”. Aguirre- 
Fernández et al., 2008b.

Genus et species novum, cf. Globicephala Lesson, 1828. Aguirre-Fernández, 2009.

“...un delfinido grande que comparte caracteres con las toninas actuales (género Tursiops) y los calderones actuales (género Globicephala)..." Aguirre-Fernández et al., 2009.

Diagnosis of genus. Medium sized odontocete cetacean with relatively short and broad rostrum, 10 teeth in each maxilla; referred to superfamily Delphinoidea because nasal bones are short and blocky and do not overhang nares, lateral lamina of pterygoid does not form a complete bony wall within orbital area, vomer is exposed in anterior part of palate, premaxillae have reduced palatal exposure anterior to palatal exposure of vomer, petrosal has short posterior process, tympanic bulla lacks anterior process, and teeth are homodont; referred to family Delphinidae because nasal bones are convex and form highest part of cranial vertex, posterior end of left premaxilla is significantly narrower and shorter than right premaxilla, posterior end of left premaxilla has reduced contact with anterolateral corner of left nasal, no premaxillary eminence is present anterior to nares; referred to subfamily Globicephalinae because rostrum is relatively broad, premaxillae are wide and occupy major part of dorsal surface of rostrum, antorbital process is large and rounded in dorsal view, tooth numbers are reduced; differing from all other genera of Globicephalinae by having proportionally longer rostrum, greater medial extension of posterior ends of right maxilla and premaxilla, and proportionally larger premaxillary sac fossae; resembling Globicephala by having wider dorsal surfaces of premaxillae on rostrum than maxillae, rugosities present on dorsal surface of anterior part of premaxilla, and facial surface of cranium extended posteriorly so that occipital shield is nearly vertical and not extensively visible in dorsal view; and differing from Globicephala by being smaller, having proportionally narrower cranium and longer and narrower rostrum, narrower dorsal exposures of premaxillae on rostrum, more convex dorsal surface of rostrum in anterior part, proportionally larger premaxillary sac fossae, greater medial expansion of posterior end of right premaxilla toward cranial vertex, more teeth, and teeth of smaller diameter. Near their anterior ends, the dorsal surfaces of the premaxillae are arched prominently, and they are elevated along their medial margins adjoining the mesorostral gutter. These features are both autapomorphies of this genus.

Type and only included species. Protoglobicephala mexicana, new species

Etymology. The genus name is a combination of the Greek word, protos, meaning first, and the generic name for the Recent pilot whales, Globicephala, which is composed of the Latin word, globus, meaning ball, and the Greek word, kephale, meaning head. The genus name Globicephala alludes to the large and spherical heads of pilot whales, to which this new dolphin is related: it is more primitive than Globicephala, but most likely, in life, did have a large and bulbous forehead.

\section{Protoglobicephala mexicana, new species}

Figures 2B, 3, 4, 5, 6, 7, Table 3

“...probable nuevo genero y especie...”. AguirreFernández et al., 2004.

"...a probable new genus and species of delphinid...". Aguirre-Fernández et al., 2005.

“...Delphinidae de Isla San José...”. Aguirre-Fernández, 2006.

"...two new genera and species of Pliocene dolphins...". Aguirre-Fernández et al., 2008a.

"Un ejemplar posee caracteres intermedios entre los géneros actuales Tursiops y Globicephala;...”. AguirreFernández et al., 2008b.

Genus et species novum, cf. Globicephala Lesson, 1828. Aguirre-Fernández, 2009.

“...un delfinido grande que comparte caracteres con las toninas actuales (género Tursiops) y los calderones actuales (género Globicephala)..." Aguirre-Fernández et al., 2009.

Holotype and only referred specimen. UABCS/ ISJ/3008, Museo de Historia Natural, Universidad Autónoma de Baja California, La Paz, Baja California Sur, Mexico. The holotype includes the cranium which lacks the ventral part of the basicranium and was found directly associated with the right petrosal, the right tympanic bulla, the right incus, and two maxillary teeth, all belonging to one adult individual.

Locality. The type locality is a slope eroded in the sea cliffs located in "Los Placeritos", Punta Colorada Basin, San Jose Island, Baja California Sur, Mexico (Fig. 1, 2B).

Formation and age. The holotype is from the lower bedded shelly sandstone portion of an unnamed Late Pliocene age deposit, approximately 3.6 to $2.5 \mathrm{Ma}$ (see Umhoefer et al., 2007).

Etymology. The species name, mexicana, is Nahuatl. The word México derives from the words: metztli ("moon"), xictli ("center"), and the suffix -co (place), thus it means "Place at the center of the moon" or "Place at the center of the Lake Moon". The species name alludes the country of discovery.

Description. Some relevant cranial measurements are described in Table 3.

Cranium. The cranium (Figs. 3-5, 7, Table 3) is relatively large compared to that of most Recent species of Delphinidae; its original condylobasal length is estimated to have been approximately $50 \mathrm{~cm}$, and its zygomatic width is estimated to have been approximately $55 \%$ of the condylobasal length. This would make it a relatively broadheaded species in comparison to most Delphinidae, but not so broad-headed as Recent species of Orcinus, Pseudorca, or Globicephala (see Fig. 7). The cranial vertex is moderately elevated. The cranial crests and tuberosities are prominent, indicating that the holotype represents an adult individual. The cranial vertex is very skewed asymmetrically to the left 


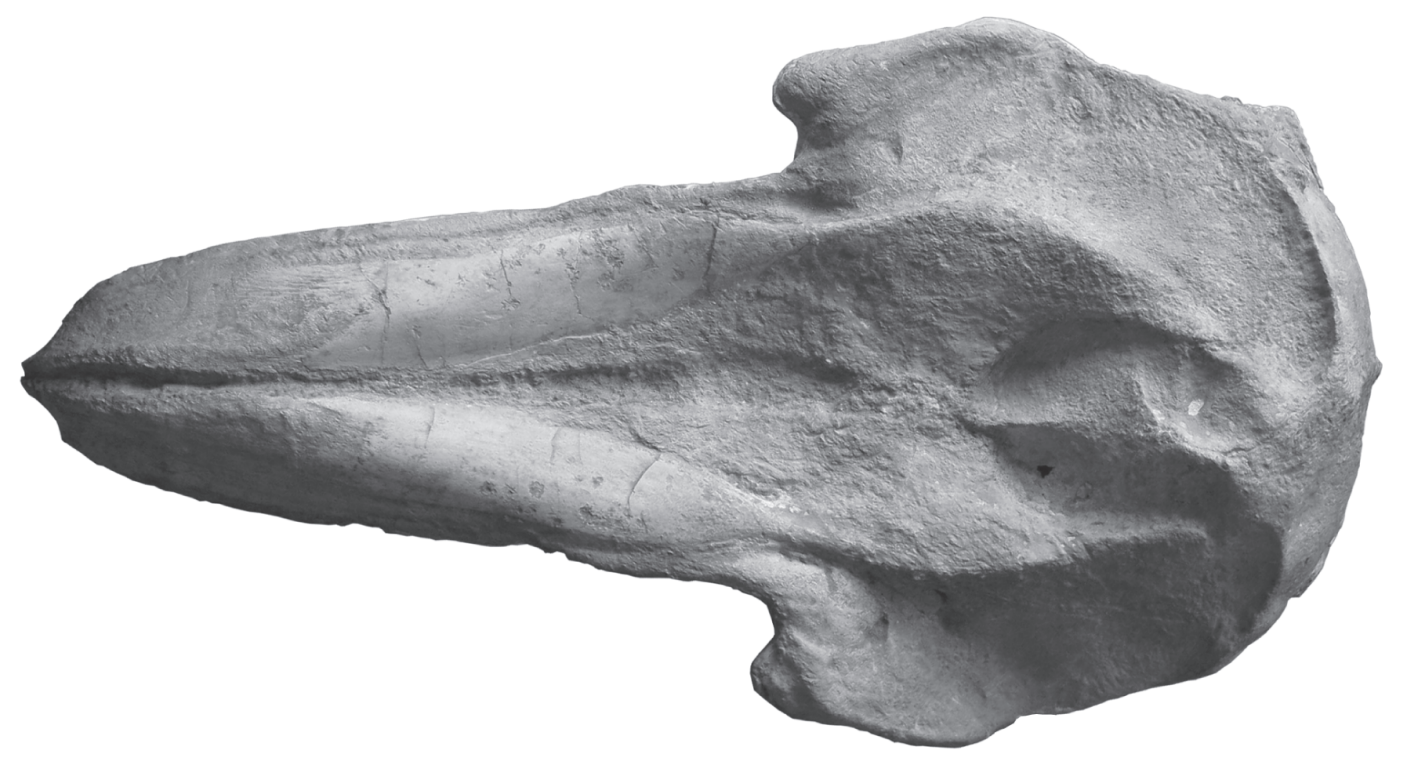

A
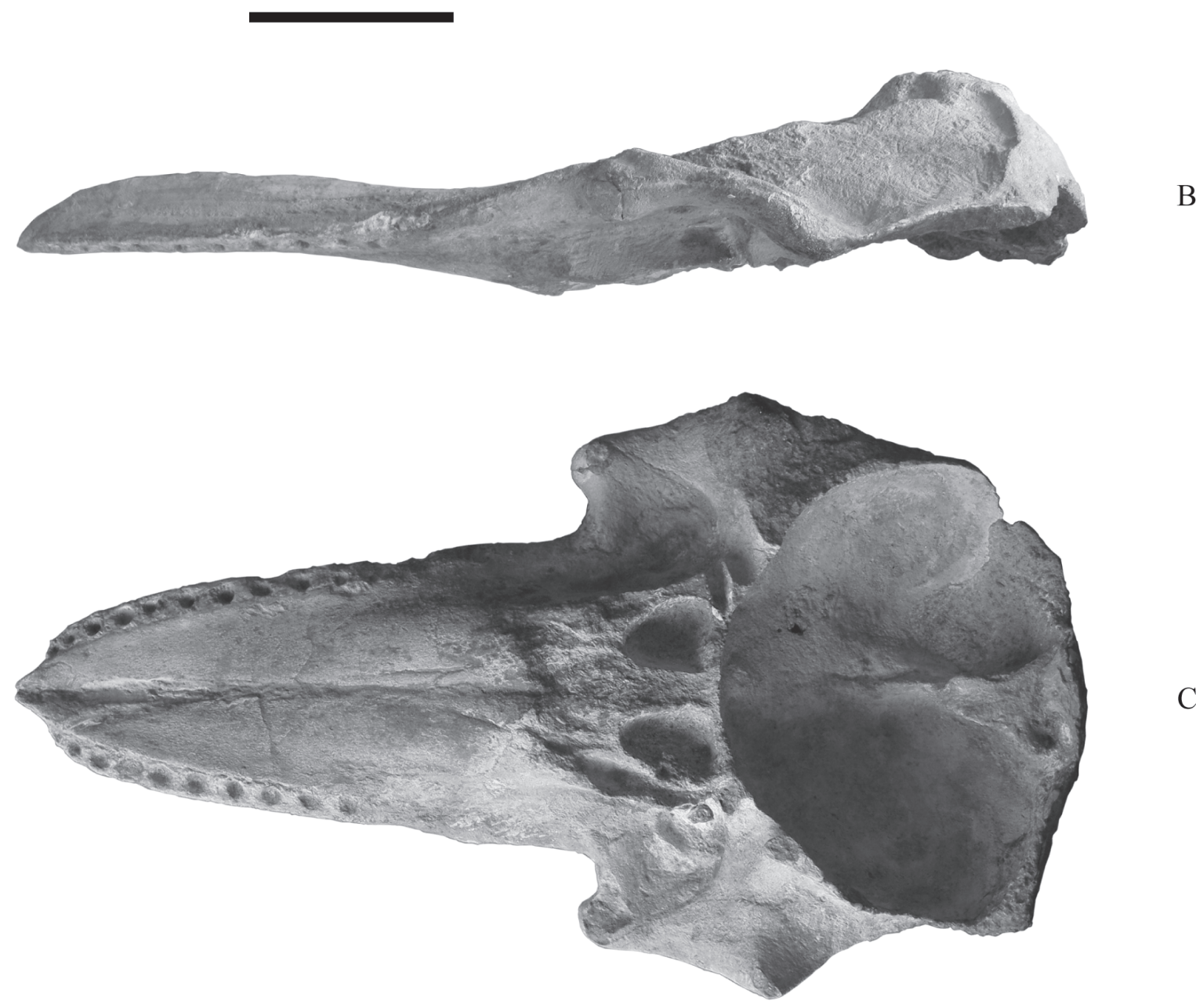

Figure 3. Protoglobicephala mexicana, new genus and new species, holotype cranium, UABCS/ISJ/3008; A, dorsal view; B, left lateral view; C, ventral view; scale bar equals $10 \mathrm{~cm}$. 


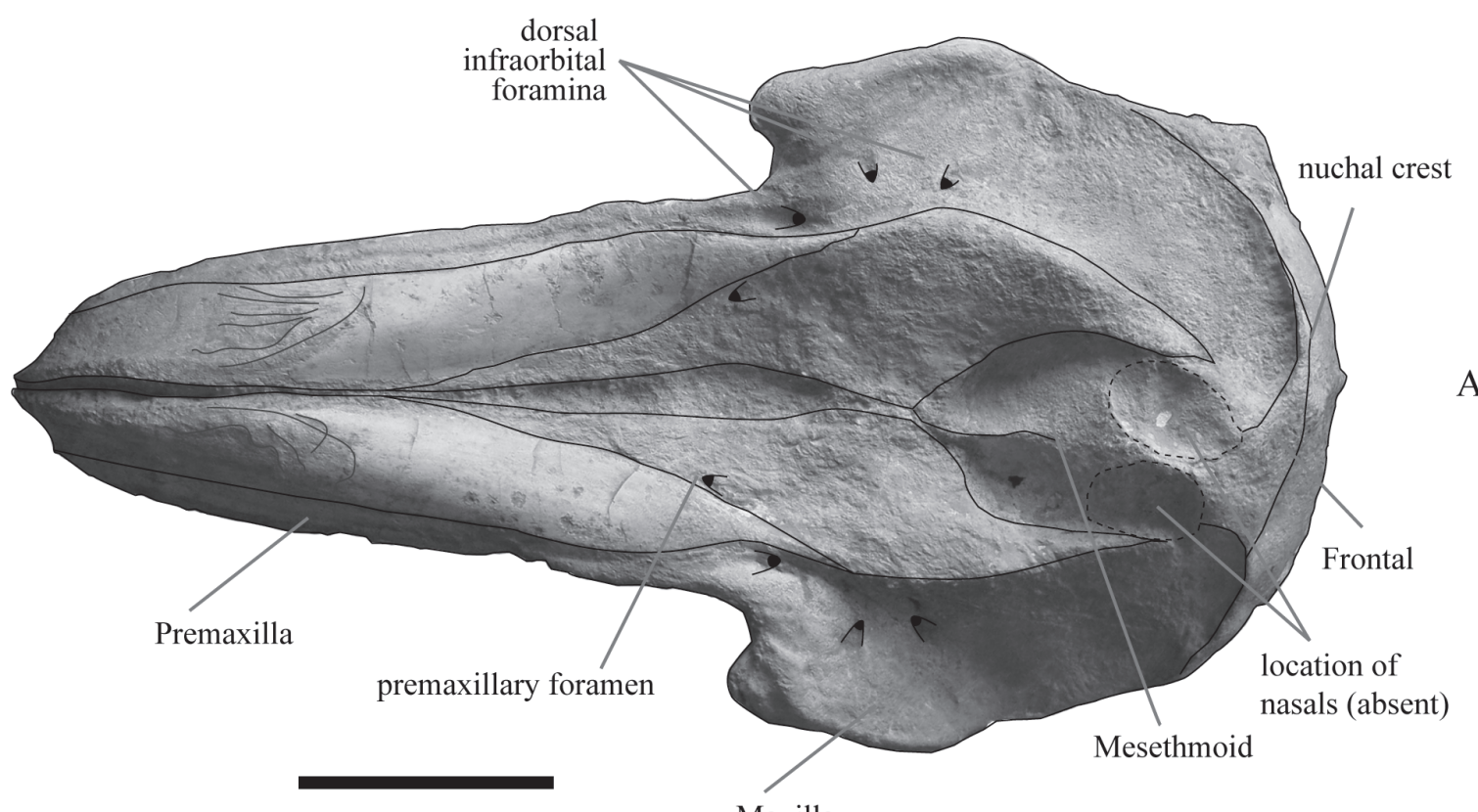

A
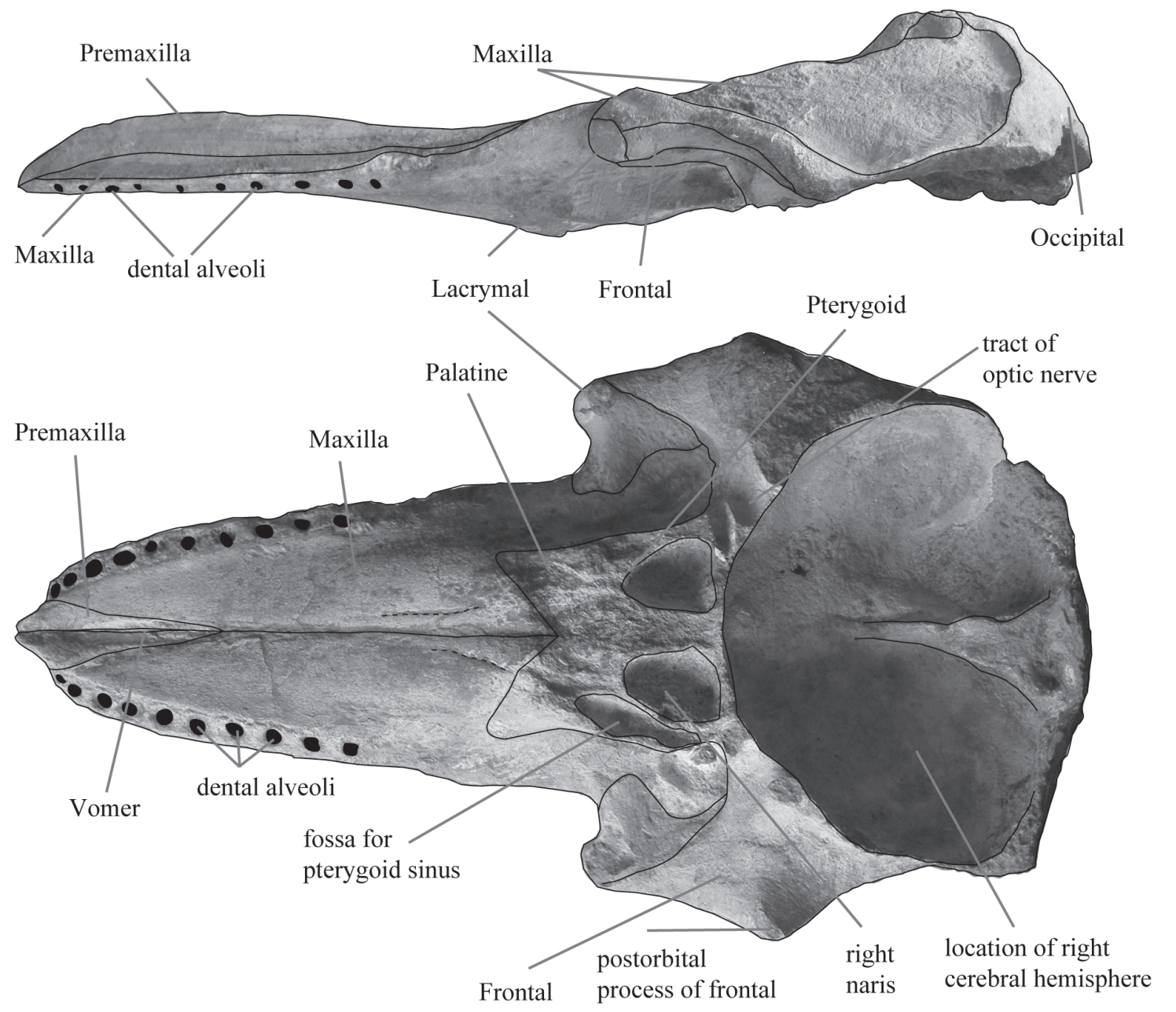

Figure 4. Protoglobicephala mexicana, new genus and new species, holotype cranium, UABCS/ISJ/3008; A, dorsal view; B, left lateral view; C, ventral view; photographs with parts labeled, individual bones outlined, and premaxillary rugosities emphasized; scale bar equals $10 \mathrm{~cm}$. 


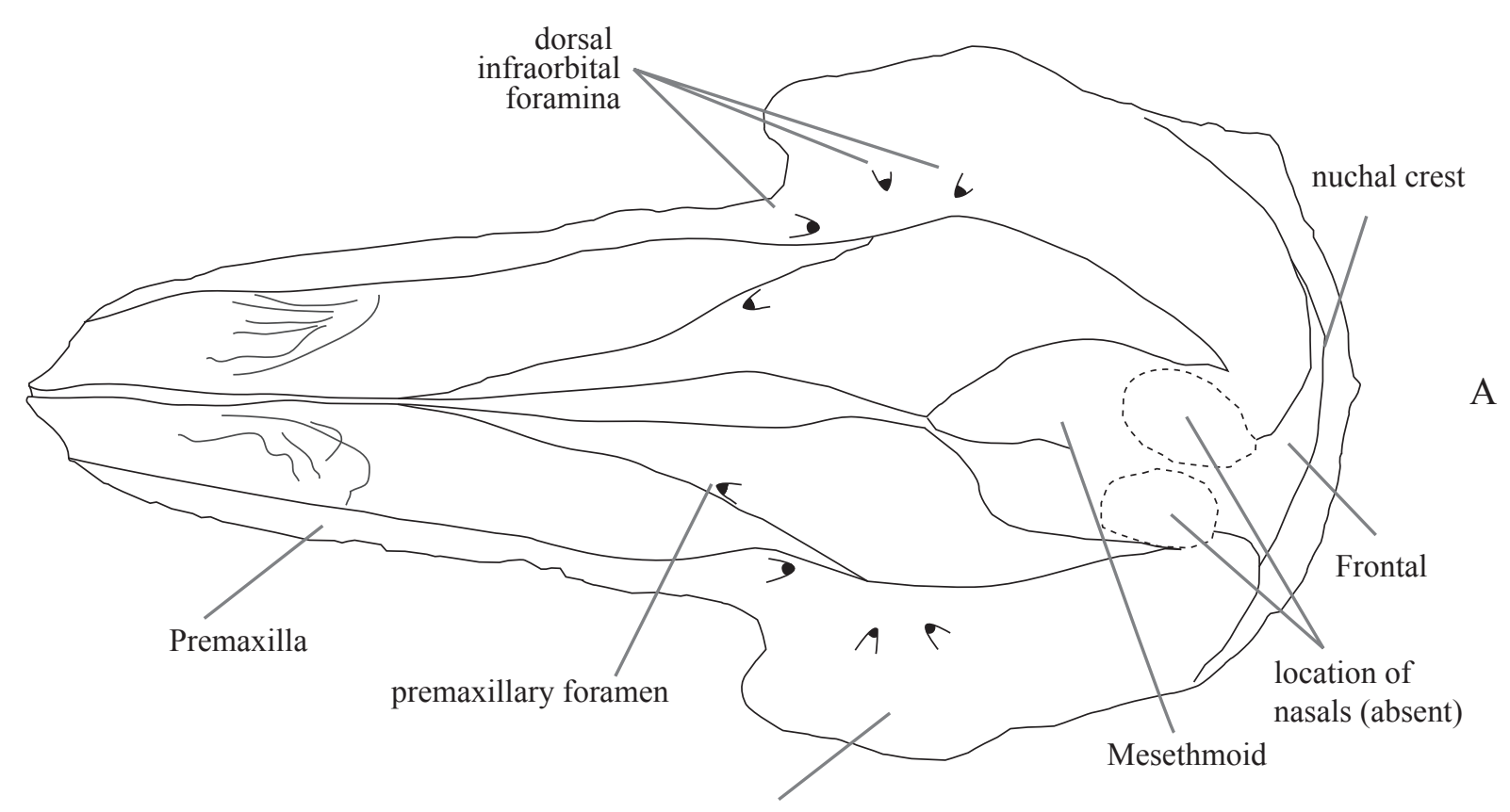

A
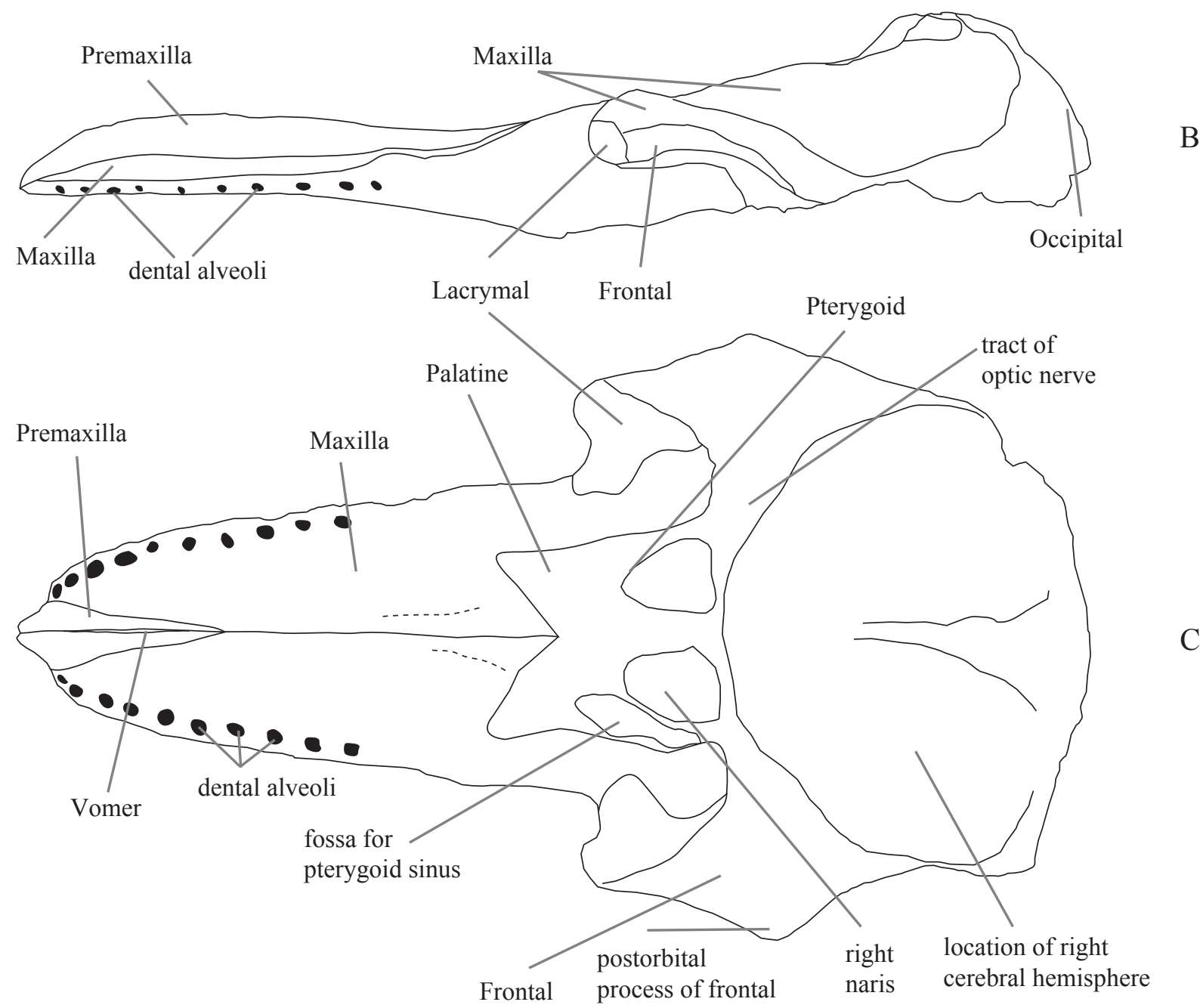

Figure 5. Protoglobicephala mexicana, new genus and new species, holotype cranium, UABCS/ISJ/3008; A, dorsal view; B, left lateral view; C, ventral view; sketches showing outlines of bones with parts labeled. 


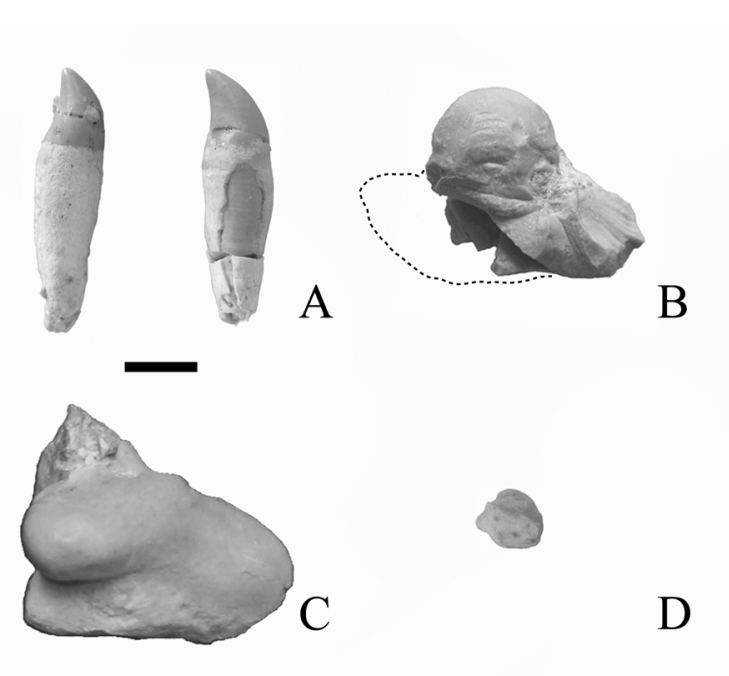

Figure 6. Protoglobicephala mexicana, new genus and new species, holotype, UABCS/ISJ/3008; A, two teeth in posterior view; B, right petrosal in ventral view (approximate reconstruction of anterior process shown by dashed line); $\mathrm{C}$, right tympanic bulla in ventral view; $\mathrm{D}$, right incus in dorsal view; scale bar equals $1 \mathrm{~cm}$, all images to the same scale.

Table 3. Measurements (in cm) of the holotype cranium of Protoglobicephala mexicana, new genus and new species, specimen UABCS/ISJ/3008; methods follow Perrin (1975). Estimation of zygomatic width is based on observations that in other delphinids examined in this study, this dimension is nearly the same as the postorbital width.

\begin{tabular}{lc}
\hline Condylobasal length (estimated) & 50.5 \\
Rostral length & 28.4 \\
Width of rostrum at base & 15.0 \\
Width of rostrum at rostral midlength & 11.2 \\
Width of premaxillae at midlength of rostrum & 9.8 \\
Greatest preorbital width & 24.5 \\
Greatest postorbital width & 27.2 \\
Least supraorbital width & 25.6 \\
Greatest width of external nares & 7.3 \\
Greatest width across the zygomatic processes (esti- & 27 \\
mated) & 13.3 \\
Greatest width of premaxillae & 24.4 \\
Greatest parietal width & 11.9 \\
Distance from anterior end of junction between nasals & \\
to posterior of margin of supraoccipital crest & 10 \\
Number of teeth in each maxilla & 1.1 \\
Diameter of dental alveolus at rostral midlength &
\end{tabular}

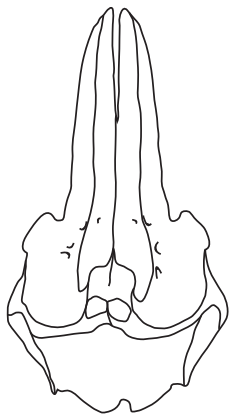

Tursiops truncatus
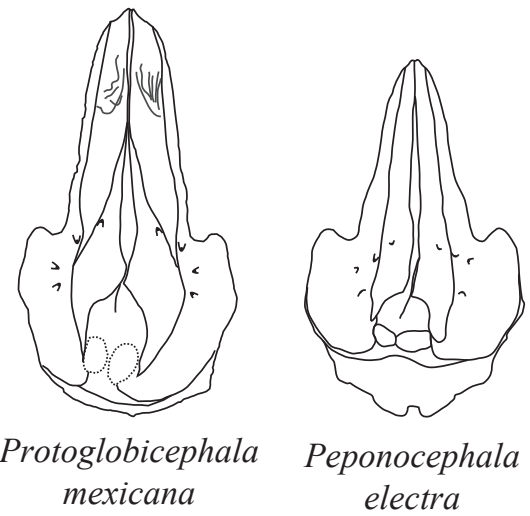

Peponocephala electra

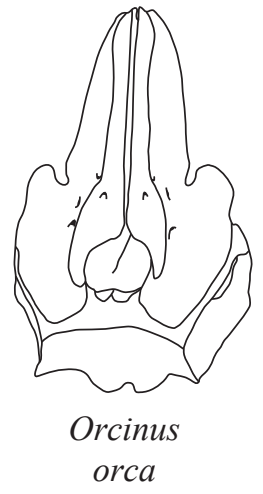

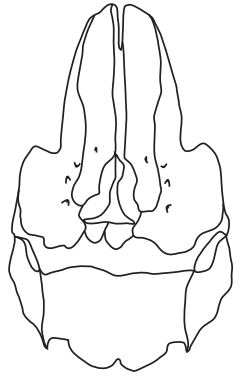

Pseudorca crassidens

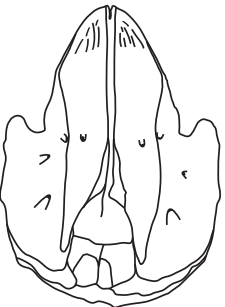

Globicephala macrorhynchus

Figure 7. Line drawings of crania, in dorsal views, of Protoglobicephala mexicana, new genus and new species, and some selected Recent species of the family Delphinidae; all images scaled to the same postorbital widths to demonstrate different proportions of the rostra and other cranial structures.

side, and accordingly the right maxilla is greatly expanded toward the cranial vertex. The right and left antorbital notches and antorbital processes are asymmetrical.

The rostrum is relatively wide, in comparison, for example, to species of Delphinus, Lagenorhynchus, or Tursiops, and on the dorsal surface of the rostrum, the premaxillae are wider than are the dorsal exposures of the maxillae. The mesorostral gutter is open dorsally in the distal $90 \mathrm{~mm}$ of the rostrum, closed over in the middle part of the rostrum, and very widely open in the posterior part of the rostrum posteriorly to a point between the orbits (Figs. 3-5).

The premaxillae form the entire extremity of the rostrum, extending anteriorly beyond the maxillae, tapering medially, and converging at the anterior end of the rostrum, where they are slightly elevated on either side of the mesorostral gutter. Near their anterior ends, the dorsal surfaces of the premaxillae are arched prominently, and they are elevated along their medial margins adjoining the mesorostral gutter. The dorsal surfaces of the distal ends of the premaxillae also have rugosities, which are similar to, but smaller than those that are present in the living species of Globicephala. We interpret these rugosities, which are not present in other species of the family Delphinidae, to be synapomorphies of Protoglobicephala and Globicephala. Although the dorsal surfaces of the premaxillae are transversely convex in the anterior one-third of the rostrum, in the posterior two-thirds 
of the rostrum they are slightly depressed medially, sloping toward the mesorostral gutter. Premaxillary foramina, one in each premaxilla, are located slightly anterior to the levels of the antorbital notches. From each premaxillary foramen three sulci originate, in the manner typical of Odontoceti (Barnes, 1978). Of these, the anteromedial sulcus converges on the margin of the mesorostral gutter, demarcating the lateral margin of the rugose area that in life includes the area of attachment of the nasal plug retractor muscle. This rugose area extends far anteriorly, to approximately the mid-length of the rostrum, in a manner that is typical of Globicephalinae, and is not typical of most other Recent species of Delphininae. The posteromedial sulcus originating from the premaxillary foramen is small and indistinct, but courses across the dorsal surface of the premaxilla obliquely toward the mesorostral gutter. The posterolateral sulcus traverses the premaxilla toward its lateral margin over the supraorbital process (Figs. 3-5).

The dorsal surfaces of the premaxillae adjacent to the dorsal narial openings are asymmetrical, the right surface being much wider than the left. Thus, the wide and slightly concave areas on either side of the nares that were in life occupied by the premaxillary sacs (see Au, 2002) are asymmetrical. The posterior end of the right premaxilla, being larger than the left, extends farther posteriorly. It appears that when the missing nasal bone was in place, in a manner similar to that in Globicephala spp., the premaxilla was close to, but did not make contact with the lateral side of the right nasal bone. The posterior end of the narrower left premaxilla, also as in Globicephala, is straight, posteriorly-directed, extended sufficiently far that it reached the mid-part of the left nasal bone, and apparently was slightly separated from the nasal bone. We could observe no exposures of the maxilla on the medial sides of the premaxillae immediately anterior to the dorsal nares, a condition that exists in some individuals and in some taxa of Delphinidae and Monodontidae (Figs. 3-5).

The maxillae, as mentioned previously, have narrower dorsal exposures on the rostrum than the premaxillae. Their lateral margins constrict abruptly at their anterior ends where they taper against the premaxillae. Immediately anterior to the rostral mid-length, the maxillae are notably lower than the adjacent premaxillae, and have a relatively sharp and abrupt lateral margin. Continuing posteriorly, toward the antorbital notches, the lateral edges of the maxillae are elevated higher than the adjacent premaxillae. On the antorbital processes, the maxillae cover the lacrymals in dorsal view, and they extend to the lateral margins of the supraorbital processes, so that the frontal bones are also not exposed in dorsal view. The antorbital processes are asymmetrical, as is commonly the case with specimens of Delphinidae. The left antorbital process is slightly larger and wider than the right, and the right antorbital process is directed slightly more anteriorly than the left, thus making its adjacent antorbital notch slightly narrower. Each maxilla has at least three major foramina. The anterior of these is medial to the antorbital notch, close to the margin of the premaxilla, and faces anteriorly. The middle foramen is located over the middle of the supraorbital process, farther from the premaxilla, and faces laterally. The posterior maxillary foramen is over the temporal fossa, and faces posterolaterally. The posterior end of the right maxilla is relatively larger than the left maxilla, and it extends relatively farther toward the mid-line of the cranium than in any of the Recent species of Delphinidae (see Fig. 7): this is an autapomorphy of Protoglobicephala mexicana.

The left nasal passage is of larger diameter than the right passage, and both nasal passages are twisted obliquely to the left side, as part of the asymmetrical skew of the cranial vertex. The midline between the nares, as indicated by the septum formed by the mesethmoid bone, is $40 \mathrm{~mm}$ to the left side of the midline of the cranium, as indicated by the ridge of bone between the cerebral hemispheres. There are no open olfactory foramina on the posterior walls of either naris. In more primitive odontocetes, the olfactory foramina are open. The mesethmoid bone covers this area on the posterior wall of the nares and extends posterodorsally, as is typical of Delphinidae (Figs 3-5).

Both nasal bones have fallen off of the cranium, and were not found. When the nasal bones were present, the mesethmoid would have contacted their ventral edges, as is also typical of Delphinidae. Judging by the fossae in the frontal bones where the nasal bones were located, they were asymmetrical, and were ovoid in shape. The fossa for the right nasal bone measures approximately 25 $\mathrm{mm}$ both anteroposteriorly and transversely, and the fossa for the left nasal bone measures approximately $18 \mathrm{~mm}$ anteroposteriorly and $14 \mathrm{~mm}$ transversely. A ridge of the frontal bone separated the two nasal bones medially, in a manner similar to Globicephala spp.

The frontals underlay the entire locations of the nasals, abutted the mesethmoid bone, and are exposed in the area of the cranial vertex between the nasal bones and the nuchal crest. The right frontal is larger than the left, and it has a larger fossa in it, located posterolateral to the fossa that formerly held the right nasal bone.

The nuchal crest is asymmetrical, its right part being much wider than the left, and extending farther posteriorly over the occipital shield than the left. The nuchal crest forms an abrupt edge at the posterior margin of the facial region, and extends posteriorly far enough to nearly obscure the occipital shield in dorsal view. This latter character is present also in species of Globicephala (Fig. 7). The supraoccipitals are slightly convex, reflecting the large brain. The anterior margins of the supraoccipitals are asymmetrical, owing to the asymmetry of the nuchal crest.

In a ventral view of the cranium (Figs. 3C, 4C and $5 \mathrm{C}$ ), the maxillae constitute most of the palatal surface. As is typical of Delphinidae, the premaxillae are exposed only in a small area at the anterior end of the palate. As is typical of delphinids that have a wide rostrum, the lateral margins of the premaxillae on the palate bow laterally, then 
they taper medially toward the extremity of the rostrum, thereby having a lanceolate shape. We cannot determine if there were teeth in the distal end of either premaxilla. The ends of the premaxillae are not perfectly preserved, and the locations of the alveolar rows along the lateral margins of both premaxillae are rugose, very much as in Globicephala spp. Thus there is no evidence of any dental alveoli in either premaxilla of Protoglobicephala mexicana, but it is possible that very small, vestigial teeth were originally present there. Some more primitive odontocetes have fully formed alveoli for incisors in the premaxillae, primitively three on each side, and some Recent species of Delphinidae have small, vestigial incisors in the premaxillae. For example, in Lagenorhynchus obliquidens, a similarly rugose area contains two small teeth that are embedded in cartilage rather than clearly defined bony alveoli, and these are vestigial incisors.

Between the posterior ends of the premaxillae and the anterior ends of the palatal exposures of the maxillae on the palate, there is only a very small and narrow palatal exposure of the vomer in a median recess. The maxillae on the palate form a wide and slightly convex surface. Each maxilla contains 10 dental alveoli: the anterior-most on each side is much smaller than the others and is located at the maxilla/premaxilla suture. The alveoli in the middle of each row are slightly larger in diameter than those toward the anterior and posterior ends

Near their posterior ends, each maxilla has a smalldiameter posterior palatine foramen, and each of these foramina is continuous with a small anteriorly-extending sulcus. On each side of the palate is an exposure of the palatine bone, each of which extends anteriorly in a pointed area of exposure. The two palatine bones, where they have sutural contact with the maxilla, form a W-shaped transverse suture line that is typical of Delphinidae. The palatines are exposed in a transverse band between the maxillae and the pterygoids. They do not have a depression reflecting any extent of anterior expansion of the pterygoid sinus onto the palate.

The pterygoid hamulae were removed from the cranium by erosion before discovery, but it is clear that, as is typical of Delphinidae, they covered much of the posterior part of the palate and underhung the ventral narial openings. The nares are separated by a relatively wide septum formed by the vomer. The fossa that held the anterior end of the right pterygoid sinus is preserved, revealing that the sinus was relatively large and ovoid in shape. The lateral lamina of the pterygoid extended posteriorly to within approximately $7 \mathrm{~mm}$ of the optic nerve canal. The ventral openings of the nares, unlike the dorsal openings, are symmetrical in size and location. At the anterolateral corner of the supraorbital process is a relatively large ventral exposure of the lacrymal bone. The ventral surface of the supraorbital process is wide and slightly concave. The path of the optic nerve lay ventral to a large and wide strut that descends from the ventral surface of the frontal bone. Anterior to this strut is an oval-shaped fossa, measuring approximately $15 \mathrm{~mm}$ by $20 \mathrm{~mm}$, which held a lobe of the pterygoid sinus.

Because the basicranium was removed by erosion, the spaces for the cerebral hemispheres are visible. This reveals that the brain was relatively large, and that it had highlyvaulted cerebral hemispheres.

Teeth. Two teeth are preserved with the holotype (Figure $6 \mathrm{~A}$ ), and were found in matrix adjacent to the cranium. Each of these teeth is $3.5 \mathrm{~cm}$ long, and the diameters of their roots coincide with the diameters $(1.1 \mathrm{~cm})$ of the dental alveoli at mid-length of the rostrum. The crowns and apical parts of the roots of these teeth are compressed anteroposteriorly, and the crown curves slightly lingually. The crowns of these teeth are otherwise essentially conical in shape, are covered in smooth enamel, and have no accessory cusps or cristae. There appear to have been 10 teeth in each upper tooth row, all of which were rooted in the maxilla, and none in the premaxilla.

Petrosal. The right petrosal (Figure 6B) was found within the cranial cavity of the holotype cranium. Its anterior process is broken off, but it is otherwise complete. In general shape, this petrosal is typical of those of species of Delphinidae: the cochlear portion is relatively large and globose, the internal acoustic meatus is relatively large and positioned obliquely on the cochlear portion, and the posterior process is large and oriented obliquely to the sagittal plane of the cranium, making it divergent from the antero-posterior axis of the petrosal. On the posterior process, the articular facet for the tympanic bulla is ovoid in shape, rugose, and slightly striated. The cochlear portion of this petrosal is not so bulbous as those of Globicephala spp., nor Orcinus orca, and in this regard is more primitive.

Tympanic bulla. The right tympanic bulla (Figure 6C) was also associated with the holotype cranium, and is nearly complete, but its anterior part and the involucrum are not preserved. The tympanic bulla has an ovoid shape, as is typical of species of the Delphinidae. The lateral groove is prominent, the posterior end is bulbous, and the articular facet for the petrosal diverges laterally from the body of the bulla. There is no anterior bullar process.

Incus. The right incus (Figure 6D) was found with the holotype, and is complete except that its crus longum is missing. It has two slightly concave facets for articulation with the malleus. Its general form is rounded and very robust, and the crus breve is short and robust.

\subsection{Comparisons}

The assignment of Protoglobicephala mexicana to the family Delphinidae is based on some apomorphies that were proposed by Muizon (1988) and Barnes (1990): the posterior end of the left premaxilla is narrower and shorter than the right one, and is retracted anteriorly away from the anterolateral corner of the left nasal so that there is little or no contact between these two bones; the mesethmoid bone extends posterodorsally up the posterior wall of the nares 
to overlap the anterior surfaces of the nasals; and the nasal bones have convex dorsal surfaces and form the highest part of the cranial vertex.

The shortening of the rostrum, the transverse expansion of the premaxillae at the anterior extremity of the rostrum, and the widening of the braincase are all characters that are present in members of the delphinid subfamily Globicephalinae (sensu Muizon, 1988). The proportion of rostrum length to the total cranial length of Protoglobicephala mexicana is similar to that observed in the Recent Tursiops truncatus, but larger than in the living species Orcinus orca, Peponocephala electra, Globicephala spp., and Pseudorca crassidens. The premaxilla of Protoglobicephala mexicana is relatively wide, having proportions similar to Pseudorca crassidens, but narrower than in the living species of Globicephala. The cranial width of Protoglobicephala mexicana is proportionally similar to Peponocephala electra and Tursiops truncatus; narrower than Orcinus orca, Pseudorca crassidens, and species of Globicephala, but much wider than in species of Delphinus, Stenella, and other delphinines. The antorbital process is robust and spherical, similar in its morphology to the same processes of Orcinus orca, Pseudorca crassidens, and species of Globicephala (Fig. 7).

The number of teeth that can be inferred from the preserved dental alveoli on the palate - 10 per maxillary dental row - is rather low compared with Delphinus and Stenella (at 40 to 50 or more per row), and is similar to the tooth count of Orcinus orca. The two preserved teeth of the specimen are unworn: their size $(3.5$ and $3.7 \mathrm{~cm}$ from crown to root) and their shapes are similar to teeth of species of Tursiops and Pseudorca. The teeth are compressed anteroposteriorly, and they have medially-curved crowns (Fig. 6A).

\subsection{Phylogenetic analysis}

The PAUP analysis resulted in two cladograms of 37 steps, both with a consistency index (CI) of 0.6757 and a retention index (RI) of 0.8554 (see Fig. 8 and 9). Within each of the two resulting cladograms, Protoglobicephala mexicana is placed within a clade that also includes Hemisyntrachelus, Orcinus, Feresa, Globicephala, Pseudorca and Grampus. The synapomorphies of this group, the subfamily Globicephalinae of some authors, are: globose and robust antorbital process of the petrosal; presence of fewer than 20 teeth per dental row; and largediameter ( $2 \%$ or the Condylobasal length) dental alveoli (indicating the presence of larger teeth).

The cladogram in Figure 8 (Hypothesis A) places Protoglobicephala mexicana basally to other members of the subfamily Globicephalinae, sharing with the living genera Orcinus, Feresa, Globicephala and Pseudorca two apomorphies: a wide rostrum measured at mid-length ( $>20 \%$ the Condylobasal length) (Character 6), and a deep and wide antorbital notch (Character 9). In the character reconstruction depicted in Figure 8, Character 4 (wide premaxilla) and Character 7 (presence of rugosities on the anterior part of the premaxilla) appear as homoplasies present in Protoglobicephala mexicana and the genus Globicephala.

The cladogram shown in Figure 9 (Hypothesis B) places Protoglobicephala mexicana as a highly derived member of the subfamily Globicephalinae, sharing with the living genera Orcinus, Feresa, Globicephala and Pseudorca the same two synapomorphies that are described above, plus a proportionally short rostrum $(<55 \%$ the Condylobasal length) (Character 1). According to this hypothesis, the genus Globicephala is the living taxon most closely related to the fossil specimen; their synapomorphy being the presence of rugosities on the anterior portion of the premaxilla (Character 7). In the character reconstruction represented in Figure 9, Protoglobicephala mexicana shows two reversals: a derived long rostrum $(60-55 \%$ the Condylobasal length) (Character 1); and a derived elevated dorsal surface of the premaxillae in the anterior portion of the rostrum (Character 3).

Both of the resulting phylogenetic hypotheses are equally parsimonious, however, we prefer phylogenetic Hypothesis B. This decision is based on our assumption that the rugosities on the dorsal surfaces of the distal ends of the premaxillae in Protoglobicephala mexicana and Globicephala spp. are not homoplasic. Such rugosities are not present in other species of Globicephalinae, Delphinidae, or Odontoceti, and apparently are related to facial musculature modifications as the melon became enlarged and extended anteriorly onto the end of the rostrum.

\section{Discussion}

\subsection{Physical maturity}

There is a wide variety of parameters to assess physical maturity in Recent dolphins. Skeletal maturation is apparently an evolutionarily fixed process that does not react to environmental forces (Calzada et al., 1997). Furthermore, criteria for assessment of skeletal maturity have the advantage of being also applicable to fossils. The degree of fusion of the vertebral epiphyses and vertebral centrum, the distal epiphyseal ossification and fusion with the metaphyses of the radius and ulna, the presence of enlarged cranial crests, the fusion of nasal bones firmly to the frontals, the wear of teeth, and the fusion of the distal portions of the premaxilla and maxilla are some parameters that can be used in Recent species of Delphinidae and other cetaceans. We assessed the maturity of the holotype of Protoglobicephala mexicana based on:

A) The distal fusion of the premaxilla-maxilla sutures: Cranial maturity can be assessed by examining the fusion of the distal portion of the premaxilla/maxilla suture (Dailey and Perrin, 1973), individuals being considered as 


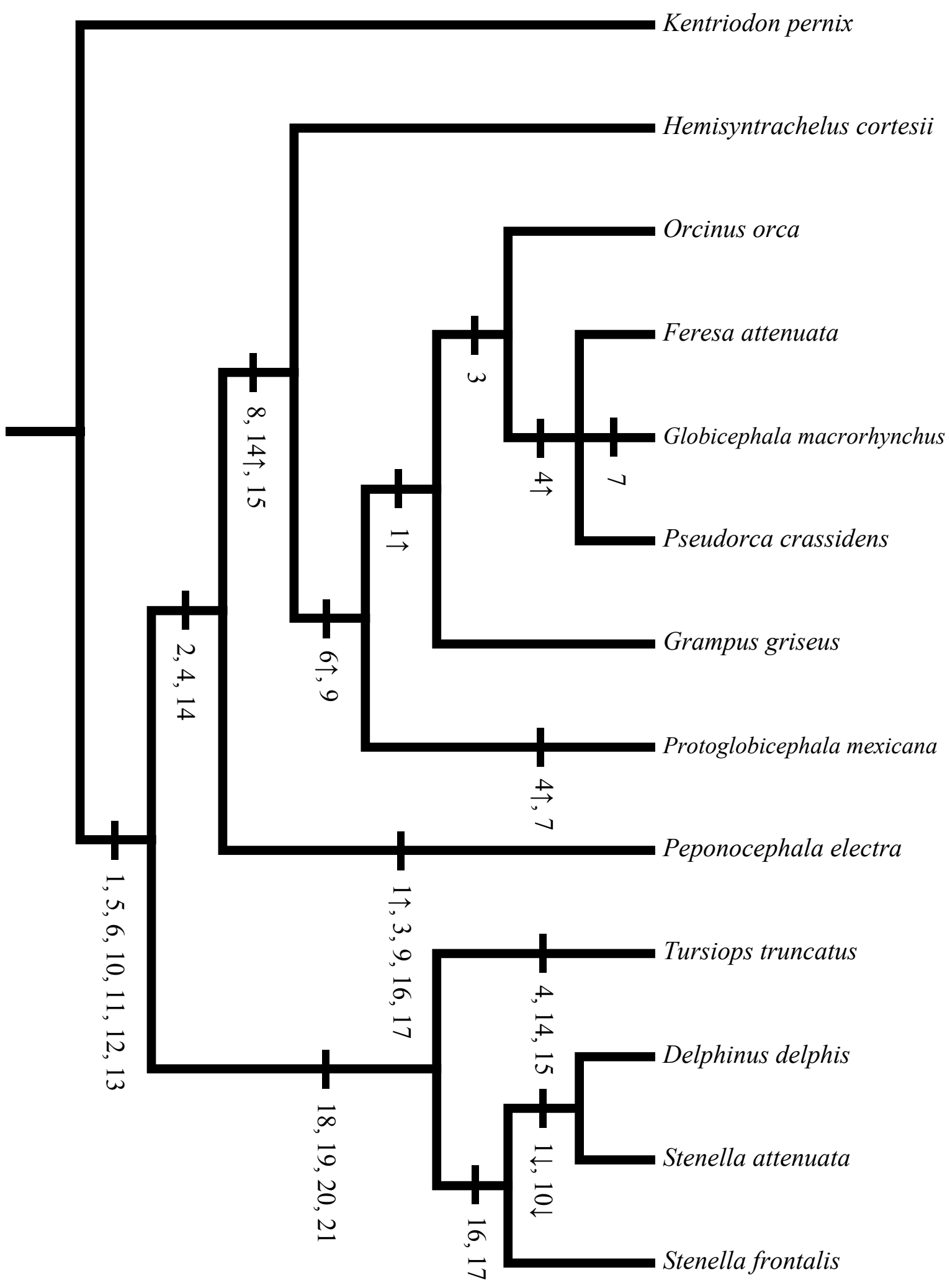

Figure 8. Postulated phylogenetic relationships (Hypothesis A) of Protoglobicephala mexicana, new genus and new species, with some selected fossil and Recent species of the family Delphinidae, and one species in the extinct delphinoid family Kentriodontidae. Number without arrow indicates change from state 0 to state $1 ; \uparrow$ indicates change from state 1 to state $2 ; \downarrow$ indicates reversal from state 1 to state 0 . 


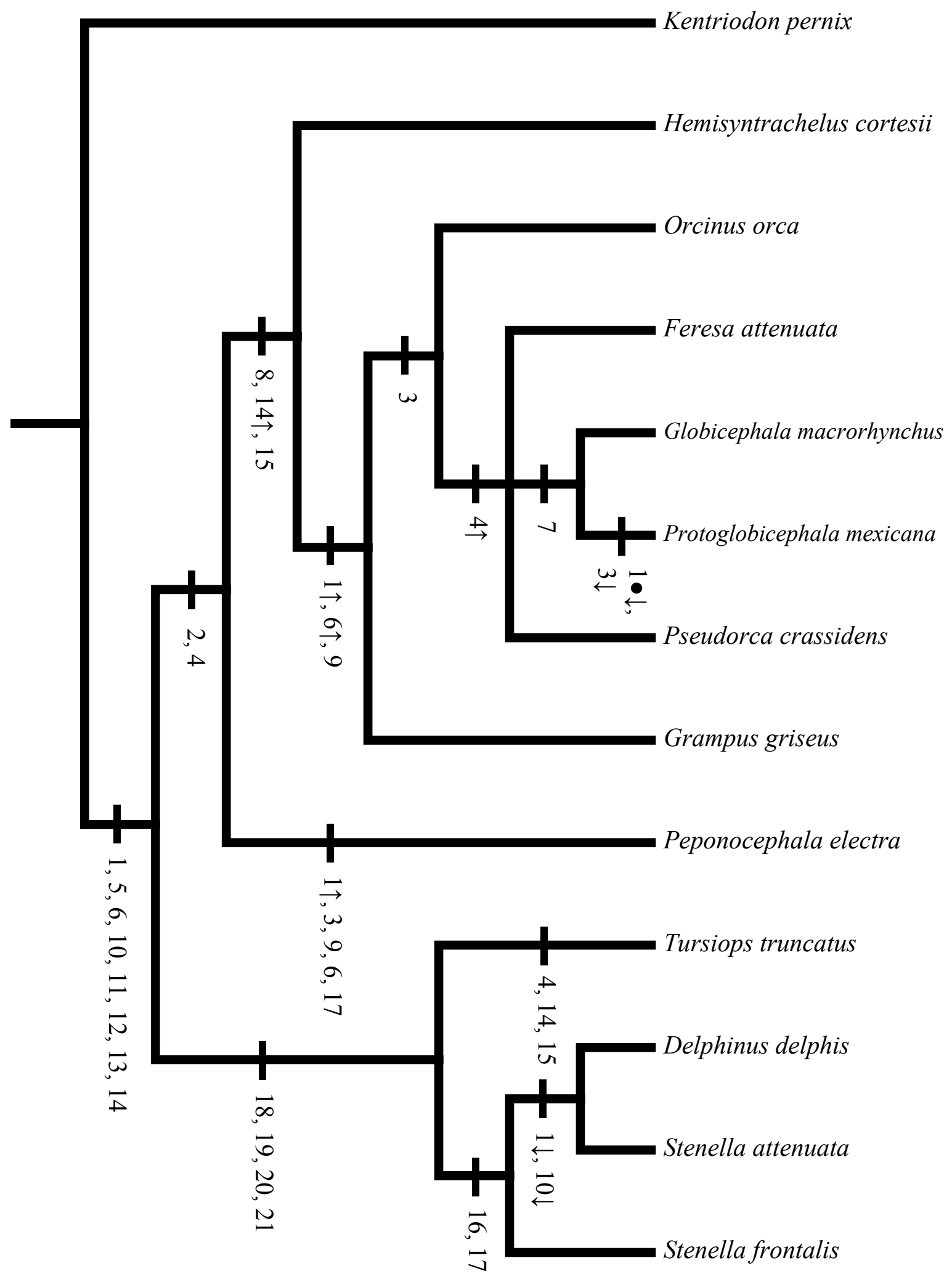

Figure 9. Alternative postulated relationships (Hypothesis B) of Protoglobicephala mexicana, new genus and new species, with some selected fossil and Recent species of the family Delphinidae, and one species in the extinct delphinoid family Kentriodontidae. Number without arrow indicates change from state 0 to state $1 ; \uparrow$ indicates change from state 1 to state $2 ; \downarrow$ indicates reversal from state 1 to state $0 ; \bullet \downarrow$ indicates reversal from state 2 to state 1 . 
immature when the suture remains unfused or the suture line is still visible, and mature when the distal portions of the premaxillary and maxillary bones are fused and the suture line is not visible. Calzada et al. (1997) determined that rostral fusion occurs in Stenella coeruleoalba at the age of 13 to 20 years. The certainty of this method is under discussion: it has been noted for some species of Recent dolphins that distal fusion of the bones is not a precise indicator of physical maturity (Perrin and Heyning (1993) for Delphinus delphis, Mead and Potter (1990) for Tursiops truncatus).

B) Presence of enlarged cranial crests: The holotype of Protoglobicephala mexicana presents a well-developed supraoccipital crest. The presence of enlarged cranial crests has been related to maturity in mammals (e.g., Elbroch, 2006).

C) Wear of teeth: The holotype of Protoglobicephala mexicana includes two unworn teeth. Extreme wear of teeth is a sign of maturity (Watson, 1981; Ramos et al., 2000). The absence of wear in the recovered teeth is the only apparent indication that the individual may not be fully mature.

Considering all of these parameters, we conclude that the holotype of Protoglobicephala mexicana was probably a young adult individual.

\subsection{Hybridization}

We note that the cranium of the holotype of Protoglobicephala mexicana is in many ways intermediate morphologically between Tursiops truncatus and more highly derived Recent globicephalines (see Fig. 7). This intermediate morphology, coupled with the apparent recency of the evolutionary diversification of the Delphinidae (Fordyce and Barnes, 1994; Barnes, 2002; Barnes et al., 2008 ), prompted an investigation into the relevance of the present-day ability of different delphinid species to interbreed and to produce viable hybrid offspring.

There are at least 39 reported cases of supposed hybridization among Recent Cetacea. Of these, $85 \%$ of the cases have been reported in the suborder Odontoceti, and most of these have involved dolphins. Of the 33 reports of hybrids among Odontoceti, 32 have occurred between members of the Delphinidae. The vast majority of these hybridizations have occurred in captivity (Sylvestre and Tasaka, 1985; Bérubé and Aguilar, 1998). The five supposed cases of hybridization that have been documented in the wild (Fraser, 1940; Reyes, 1996; Yazdi, 2002) were not substantiated genetically, which might render their validity questionable.

It is noteworthy that 30 out of the 32 cases of hybridization in the Delphinidae involved Tursiops truncatus as one of the parents (Sylvestre and Tasaka, 1985; Bérubé and Aguilar, 1998; Zornetzer and Duffield, 2003). The other two reports within the family Delphinidae document one possible cross between Delphinus capensis and Lagenorhynchus obscurus (Reyes, 1996), and one possible cross between Lissodelphis borealis and Lagenorhynchus obscurus (Yazdi, 2002).

Hybridization cases that seem relevant to the intermediate morphology of the Protoglobicephala mexicana holotype are:

1) The six cases of Tursiops truncatus $\mathrm{x}$ Pseudorca crassidens (Bérubé, 2002). In one of these cases, the hybrid back-crossed with a Tursiops truncatus, having two living calves, and one second-generation hybrid survived for eight years (Duffield and Amos, 2001). No measurements or skeletal descriptions are available for these animals. There is only one reference that includes skeletal characteristics and measurements of a Tursiops truncatus x Pseudorca crassidens hybrid; unfortunately, it describes a calf that survived only 277 days (Nishiwaki and Tobayama, 1982), making any comparison difficult.

2) The two cases of hybridization of Globicephala macrorhynchus x Tursiops truncatus (Duffield, 1988, in Bérubé, 2002). In one of these cases, the offspring was stillborn. There is no information about skeletal characteristics, so it is impossible to compare directly characteristics and measurements with the other mentioned cases.

The ability of different species to hybridize implies a small genetic distance between those species. Small genetic separation is in accord with a scenario of relatively recent and rapid evolutionary radiation of the Delphinidae. Such rapid diversification would provide time for the development of relatively few distinctive characters, and the lack of distinctive characters can make taxonomic work with the group difficult (Pichler et al., 2001). The number of cases of delphinid hybridizations probably signals close genetic relationships among the Recent species of purportedly different genera of delphinids, some of which are typically classified even in different subfamilies of the Delphinidae, thus reinforcing previous hypotheses of a rapid and relatively recent diversification of this family (Barnes, 2002).

\subsection{Phylogenetic considerations}

It is not the intention of this study to provide a phylogenetic revision of the family Delphinidae, nor an interpretation of the evolutionary relationships of the living taxa. The description and phylogenetic hypothesis proposed in this study (Figs. 8 and 9) are intended to place in context the new fossil species, Protoglobicephala mexicana, in order to propose some general ideas about its evolutionary relationships and to help in future, more comprehensive analyses. As has been pointed out in recent phylogenetic analyses, much work remains to be done specifically with the Delphinidae (LeDuc et al., 1999; Price et al., 2005). The lack of information about relationships among some groups of Cetacea also mirrors the deficiency regarding other aspects of their biology, illustrated by the fact that, for example, $53 \%$ of the living species of the Delphinidae are categorized in the Red List of Endangered Species of 
the IUCN (www.redlist.org) as data deficient (Price et al., 2005).

The general interrelationships shown by the cladograms proposed here are similar to those proposed by Muizon (1988), Barnes (1990) and Bianucci (1996, 2005), representing two main clades within the Delphinidae: the subfamily Delphininae, including species of such genera as Tursiops, Delphinus and Stenella, etc., and the subfamily Globicephalinae, which includes, according to our conclusions, the Pliocene fossil Protoglobicephala mexicana (Figs. 8 and 9).

Bianucci $(1996,2005)$ suggested that some genera of the Delphinidae having similar morphologies related to the feeding apparatus (rostral proportions, numbers and sizes of teeth) could have originated from independent evolutionary lineages via convergent evolution. If that were true, then the subfamilies Delphininae and Globicephalinae would be polyphyletic groups, whose members simply have developed similar trophic adaptations.

The experiments, simulations, and biomechanical models studied by Werth $(1992,2006 a, 2006 b)$ indicate a positive correlation between the employment of suction feeding (documented or inferred from prey, stomach contents, feeding behavior and muscular-skeletal anatomy) and a cranial morphology that includes having a short and blunt head with a large and round oral aperture. These characteristics, however, are not restricted to just one odontocete family, and it is more likely that they originated independently multiple times within the suborder Odontoceti (Werth, 2006a). For that reason, we avoided relying heavily upon these characters in our phylogenetic analysis

\section{Conclusions}

A new genus and species of extinct odontocete, Protoglobicephala mexicana, is based upon a fossil specimen from San José Island in the Gulf of California, Baja California Sur, Mexico. The holotype and only known specimen of this species was discovered in an un-named shallow-water marine deposit, and is between approximately 2.2 or 2.4 million years and $3.6 \pm 0.5$ million years in age (Figs. 1 and 2A). The specimen includes the nearly complete cranium (Figs. 2B, 3-5, Table 3), two teeth, a petrosal, a tympanic bulla, and an incus (Fig. 6 A-D). Protoglobicephala mexicana is a member of the relatively diverse living family of pelagic dolphins, the Delphinidae. Among the living delphinids, it shares important characters with living pilot whales of the genus Globicephala, and we therefore assign it to the delphinid subfamily Globicephalinae, even though in its cranial proportions it somewhat resembles the relatively generalized living species of bottlenose dolphins of the genus Tursiops. The most parsimonious conclusion is that the intermediate morphology of Protoglobicephala mexicana in comparison to different living delphinid species does not indicate an event of hybridization. The generalized features of Protoglobicephala mexicana add to growing evidence from various lines of research indicating that the present high diversity of the family Delphinidae is the result of relatively recent and rapid evolutionary diversification. One of these is the ability of living delphinid species in different genera to interbreed and to produce viable hybrid offspring.

\section{Acknowledgments}

We thank Dr. Daryl P. Domning and an anonymous revisor for their reviews and useful comments, which helped in a great way to improve this paper.

The holotype of Protoglobicephala mexicana was first discovered by Mr. Pieter A. Folkens during an eco-tourism expedition that visited Isla San José. We acknowledge Mr. Folkens for making this discovery, and we thank Dr. John M. Harris and Ms. Diana Weir for the subsequent re-discovery of the specimen during a later cruise of the ship "Don Jose", which was operated by Baja Expeditions, as part of the Members Travel Program of the Natural History Museum of Los Angeles County. For assistance during the latter cruise, we thank the owner of Baja Expeditions, Mr. Tim Means, and the employees of his organization, the diligent ship captain, Sr. Jose Lozano Cabrera, and his very helpful crew members Sr. Luis Alberto Ruiz, Sr. Jose Felix Higuera, Sr. Hernan Parra Mendivil, Sr. Roberto Paulo Dario, and Sr. Cesar Enrique Aguilar.

For subsequent permission and support to collect the specimen, we thank the Area de Proteccion de Flora y Fauna Islas del Golfo de California and the Instituto Nacional de Antropología e Historia (INAH) in La Paz. For support and assistance during this project, we thank the faculties and staffs of the Universidad Autónoma de Baja California Sur (UABCS), especially Dr. Gerardo González-Barba and Dr. Tobias Schwennicke; of the Centro Interdisciplinario de Ciencias Marinas (CICIMAR) in La Paz, especially Dra. Diane Gendron and Dr. David Aurioles-Gamboa; of the Universidad Autónoma de Baja California (UABC) in Ensenada, especially Dr. Jorge Ledesma-Vázquez; of the Universidad Nacional Autónoma de México (UNAM) in Mexico City, especially Dr. Fernando A. Cervantes and $\mathrm{M}$. en C. Yolanda Hortelano-Moncada; and of the Natural History Museum of Los Angeles County (LACM), especially Mr. James P. Dines and Mr. David S. Janiger.

Aguirre wishes to personally thank Biol. Luis Alberto Herrera-Gil, Dr. Jorge Urbán-Ramírez, Dr. Lawrence G. Barnes, M. en C. Enrique Alejandro Gómez-Gallardo, and M. en C. Héctor Pérez-Cortés Moreno for their guidance and assistance during the research for a Bachelor's thesis at UABCS, and Drs. Francisco Javier Aranda Manteca, Lawrence G. Barnes, and Miguel A. Téllez-Duarte for their guidance and assistance during research for a Master's thesis at UABC. The holotype was part of the research for both of 
these theses by Aguirre. Aguirre received a scholarship from Consejo Nacional de Ciencia y Tecnología (CONACYT) to complete his Master's thesis, and a grant from the Cetacean Society International for his research visit to LACM.

This study was made possible by support and assistance from the Natural History Museum of Los Angeles County and its Foundation through the Fossil Marine Mammal Research Account and by generous donations from Ronald and Judith Perlstein, Ms. Donna Matson, Mr. Lou Marienthal and Mrs. Dena Marienthal, Dr. John Minch, and Mr. James E. Klein and Mrs. Sally Klein. We thank Mr. Howell W. Thomas, Vertebrate Paleontology Laboratory Supervisor at the LACM for assistance in making replicas of the holotype.

\section{References}

Aguirre-Fernández, G., 2006, Descripción taxonómica de un cráneo fósil de odontoceto (Delphinidae) del Plioceno de Isla San José, Baja California Sur, Mexico: La Paz, Baja California Sur, México, Universidad Autónoma de Baja California Sur, Bachelor's Thesis.

Aguirre-Fernández, G., 2009, Delphinidae (Cetacea: Odontoceti) del Plioceno del Golfo de California, una revisión filogenética: Ensenada, Baja California, México, Universidad Autónoma de Baja California, Master's Thesis.

Aguirre-Fernández, G., Barnes, L.G., Herrera-Gil, L.A., Fernández-Rivera, J.R., 2004, Sobre el descubrimiento de un cráneo fósil de delfinido, probable nuevo genero y especie, del Plioceno de Isla San José, Baja California Sur, México (abstract), in Programa y Resúmenes XXIX Reunión Internacional para el Estudio de los Mamíferos Marinos: La Paz, Baja California Sur, México, Sociedad Mexicana de Mastozoología Marina, 67.

Aguirre-Fernández, G., Barnes, L.G., Herrera-Gil, L.A., FernándezRivera, J.R., 2005, Discovery of a fossil cranium of a probable new genus and species of delphinid in Pliocene deposits at Isla San José, Baja California Sur, México (abstract), in Memorias VII Reunión Internacional sobre Geología de la Península de Baja California: Ensenada, Baja California, México, Sociedad Geológica Peninsular, 42-43.

Aguirre-Fernández, G., Aranda-Manteca, F.J., Barnes, L.G., FernándezRivera, J.R., 2008a, Phylogenetic history of Delphinidae (Cetacea: Odontoceti) during the Pliocene of the Gulf of California (abstract) in Abstract book of 22nd Annual Conference of the European Cetacean Society: Egmond Aan Zee, The Netherlands, 175-176.

Aguirre-Fernández, G., Barnes, L.G., Aranda-Manteca, F.J., FernándezRivera, J.R., 2008b, Afinidades filogenéticas de algunos Delphinidae (Cetacea: Odontoceti) del Golfo de California, México, durante el Plioceno (abstract) in Programa y Resúmenes XXXI Reunión Internacional sobre el Estudio de los Mamíferos Marinos: Ensenada, Baja California, México, Sociedad Mexicana de Mastozoología Marina, 20.

Aguirre-Fernández, G., Aranda-Manteca, F.J., Barnes, L.G., FernándezRivera, J.R., 2009, Los Delphinidae (Cetacea: Odontoceti) del Plioceno del Golfo de California; implicaciones sobre la evolución de la familia (abstract) in Resúmenes del XI Congreso Nacional de Paleontología: Juriquilla, Querétaro, México, Sociedad Mexicana de Paleontología, 4.

Aranda-Manteca, F.J., Barnes, L.G., Aguirre-Fernández, G., 2008, Condiciones ambientales y tectónica durante el Plioceno en el desarrollo de la familia Delphinidae en el Golfo de California, México (abstract) in Programa y Resúmenes XXXI Reunión Internacional sobre el Estudio de los Mamíferos Marinos: Ensenada, Baja California, México, Sociedad Mexicana de Mastozoología Marina, 22.
Aranda-Manteca, F.J., Aguirre-Fernández, G., Barnes, L.G., 2009, Condiciones ambientales y tectónicas durante el Plioceno en el desarrollo de la Familia Delphinidae en el Golfo de California, México (abstract) in Resúmenes del XI Congreso Nacional de Paleontología: Juriquilla, Querétaro, México, Sociedad Mexicana de Paleontología, 9.

Au, W.L., 2002, Echolocation, in Perrin, W.F., Thewissen, H., Wursig, B. (eds.), Encyclopedia of Marine Mammals: San Diego, California, U.S.A., Academic Press, 358-367.

Barnes, L.G., 1978, A review of Lophocetus and Liolithax and their relationships to the delphinoid family Kentriodontidae (Cetacea: Odontoceti): Natural History Museum of Los Angeles County Science Bulletin, 28, 1-35.

Barnes, L.G., 1990, The fossil record and evolutionary relationships of the genus Tursiops, in Leatherwood, S., Reeves, R.R. (eds.), The bottlenose dolphin: San Diego, California, U.S.A., Academic Press, 3-26.

Barnes, L.G., 2002, Delphinoids: Evolution of the modern families, in Perrin, W.F., H. Thewissen, Wursig, B. (eds.), Encyclopedia of Marine Mammals: U.S.A., Academic Press, 314-316.

Barnes, L.G., Thomas, H.W., McLeod, S.A., Bohaska, D.J., Godfrey, S.J., Pyenson, N.D., Goedert, J.L., Aranda-Manteca, F.J., AguirreFernández, G., 2008, Evolutionary diversity and determination of character polarity in primitive Miocene delphinoids, the Kentriodontidae (Cetacea, Odontoceti, Kentriodontidae) (abstract) in Programa y Resúmenes, XXXI Reunión Internacional sobre el Estudio de los Mamíferos Marinos: Ensenada, Baja California, México, Sociedad Mexicana de Mastozoología Marina, 21.

Bérubé, M., 2002, Hybridism, in Perrin, W.F., H. Thewissen, Wursig, B. (eds.), Encyclopedia of Marine Mammals: U.S.A., Academic Press, 596-600.

Bérubé, M., Aguilar, A., 1998, A new hybrid between a blue whale, Balaenoptera musculus, and a fin whale, B. physalus: frequency and implications of hybridization: Marine Mammal Science, 14(1), 82-98.

Bianucci, G., 1996, The Odontoceti (Mammalia, Cetacea) from Italian Pliocene. Systematics and phylogenesis of Delphinidae: Palaeontographia Italica, 83, 73-167.

Bianucci, G., 2001, A new genus of Kentriodontid (Cetacea: Odontoceti) from the Miocene of South Italy: Journal of Vertebrate Paleontology, 21(3), 573-577.

Bianucci, G., 2005, Arimidelphis sorbinii a new small killer whale-like dolphin from the Pliocene of Marecchia River (Central Eastern Italy) and a phylogenetic analysis of the Orcininae (Cetacea: Odontoceti): Rivista Italiana di Paleontologia e Stratigrafia, 111(2), 329-344.

Bonner, N., 1989, Whales of the world: New York, U.S.A., Facts on File.

Brandt, J.F., 1873, Untersuchungen über die fossilen und subfossilen cetaceen Europa's: Mémoires De L'Académie Impériale Des Sciences De Saint-Petersbourg Series 7, 20, 1-372.

Brisson, M.J., 1762, Regnum animale in classes IX distributum, sive synopsis methodica sistens generalem animalium distributionemin classes IX, \& duarum primarum classium, quadripedum sciliet \& cetaceorum, particularum divisionem in ordines, sectiones, genera, $\&$ species: Leiden, Theodorum Haak, Lugduni Batavorum.

Calzada, N., Aguilar, A., Lockyer, C., Grau, E., 1997, Patterns of growth and physical maturity in the western Mediterranean striped dolphin, Stenella coeruleoalba (Cetacea: Odontoceti): Canadian Journal of Zoology, 75, 632-637.

Dailey, M.D., Perrin, W.F., 1973. Helminth parasites of porpoises of the genus Stenella in the eastern tropical Pacific, with descriptions of two new species: Mastigonema stenellae gen. et sp. n. (Nematoda: Spiruroidea) and Zalophotrema pacificum sp. n. (Trematoda: Digenea): Fishery Bulletin, 71(2), 455-471.

Deméré, T.A., 1993, Fossil mammals from the Imperial Formation (Upper Miocene/Lower Pliocene, Coyote Mountains, Imperial County, California, in Reynolds, R.E., Reynolds, J.E. (eds.), Ashes, faults and basins: San Bernardino, California, U.S.A., San Bernardino County Museum Association Special Publication 93-1, 82-85. 
Duffield, D.A., Amos, W., 2001, Genetic analyses, in Dierauf, L.A., Gulland, F.M.D. (eds.), CRC Handbook of Marine Mammal Medicine: Boca Raton, Florida, U.S.A., CRC Press, 271-278.

Elbroch, M., 2006, Animal Skulls, a Guide to North American Species: U.S.A., Stackpole Books, 1-740.

Evans, P.G.H., 1987, The natural history of whales and dolphins: London, Great Britain, Christopher Helm.

Fitzinger, L.J., 1860, Wissenschaftlich-populäre Naturgeschichte der Säugethiere in ihren sämmtlichen Hauptformen. Nebst einer Einleitung in die Naturgeschichte überhaupt un in die Lehre von den Thieren insbesondere: Vienna, Am der Kaiserlich-Königlichen Hof-und Staatsdruckerei.

Flower, W.H., 1865, Notes on the skeletons of whales in the principal museums of Holland and Belgium, with descriptions of two species apparently new to science: Proceedings of the Zoological Society of London, 1864, 384-420.

Flower, W.H., 1867, Description of the skeleton of Inia geoffrensis and of the skull of Pontoporia blainvillei, with remarks on the systematic position of these animals in the order Cetacea: Transactions of the Zoological Society of London, 6, 87-116.

Fordyce, R.E., Barnes, L.G., 1994, The evolutionary history of whales and dolphins: Annual Review of Earth and Planetary Sciences, $22,419-455$

Fraser, F.C., 1940, Three anomalous dolphins from Blacksod Bay, Ireland Proceedings of the Royal Irish Academy, 45 (Sec. B), 413-455.

Fraser, F.C. Purves, P.E., 1960, Hearing in Cetaceans: Evolution of the accessory air sacs and the structure and function of the outer and middle ear in Recent cetaceans: Bulletin of the British Museum of Natural History, 7, 1-140.

Gray, J.E., 1821, On the natural arrangement of vertebrose animals: London Medical Repository, 15, 296-310.

Gray, J.E., 1828, Spicilegia zoological; or original figures and short systematic descriptions of new and unfigured animals: London, Würtz \& Co.

Gray, J.E., 1866, Catalogue of seals and whales in the British Museum, Second Edition: London, British Museum.

Gray, J.E., 1870, Notes on the arrangement of the genera of delphinoid whales: Proceedings of the Zoological Society of London, 1-2.

Heyning, J.E., Perrin, W.F., 1991, Re-examination of two forms of common dolphins (genus Delphinus) from the Eastern North Pacific; evidence for two species: La Jolla, California, U.S.A., National Oceanographic and Atmospheric Administration, Administrative Report LJ-91-28, 1-37.

Helenes, J., Carreño, A.L., 1999, Neogene sedimentary evolution of Baja California in relation to regional tectonics: Journal of South American Earth Sciences, 12, 589-605.

Kasuya, T., 1973, Systematic consideration of Recent toothed whales based on the morphology of tympano-periotic bone: Scientific Reports of the Whales Research Institute, 25, 1-103.

Kellogg, R., 1927, Kentriodon pernix, a Miocene porpoise from Maryland: Proceedings of the United States National Museum, 69, 1-55.

Ledesma-Vázquez, J., 2002, A gap in the Pliocene invasion of seawater to the Gulf of California: Revista Mexicana de Ciencias Geológicas, 19(3), 45-151.

LeDuc, R.G., 2002, Delphinids, Overview, in Perrin, W.F., Thewissen, H., Wursig, B. (eds.), Encyclopedia of Marine Mammals: U.S.A., Academic Press, 310-314.

LeDuc, R.G., Perrin, W.F., Dizon, A.E., 1999, Phylogenetic relationships among the delphinid cetaceans based on full cytochrome $b$ sequences: Marine Mammal Science, 15(3), 619-648.

Lesson, R.P., 1828, Histoire Naturelle, Générale et Particulière des Mammifères et des Oiseaux Découverts depuis 1788 jusqu'à nos Jours, Complément des oeuvres de Buffon, ou historie naturelle des animaux rares découverts par les naturalistes et les voyageurs depuis la mort de Buffon. Tom. 1 Cétacés: Paris, Baudoin Frères.

Lesson, R.B., 1842, Nouveau tableau du règne animal, Mammifères: Paris, Roret.

Martín-Barajas, A., 2000, Volcanismo y extensión en la Provincia Extensional del Golfo de California: Boletín de la Sociedad
Geológica Mexicana, 53, 72-83.

Mead, J.G., 1975, Anatomy of the external nasal passages and facial complex in the Delphinidae (Mammalia: Cetacea): Smithsonian Contributions to Zoology, 207, 1-72.

Mead, J.G., Potter, C.W., 1990, Natural history of bottlenose dolphins along the central Atlantic coast of the United States, in Leatherwood, S., Reeves, R.R. (eds.), The bottlenose dolphin: San Diego, California, U.S.A., Academic Press, 165-195.

Miyasaki, N., Amano, M., 1994, Skull morphology of two forms of shortfinned pilot whales off the Pacific coast of Japan: Reports of the International Whaling Commission, 44, 499-508.

Muizon, C. de, 1988, Les relations phylogénétiques des Delphinida (Cetacea, Mammalia): Annales de Paléontologie, 74(4), 159-227.

Nishiwaki, M., 1963, Taxonomical consideration on genera of the Delphinidae: Scientific Reports of the Whales Research Institute, 17, 93-104.

Nishiwaki, M., Norris, K.S., 1966, A new genus, Peponocephala, for the odontocete cetacean species Electra electra: Scientific Reports of the Whales Research Institute, 20, 95-100.

Nishiwaki, M., Tobayama, T., 1982, Morphological study on the hybrid between Tursiops and Pseudorca: Scientific Reports of the Whales Research Institute, 34, 109-121.

Perrin, W.F., 1975, Variation of spotted and spinner porpoise (genus Stenella) in the Eastern Tropical Pacific and Hawaii: Bulletin of the Scripps Institution of Oceanography, University of California Press, 21, 1-206.

Perrin, W.F., 1989, Dolphins, porpoises, and whales: An action plan for the conservation of biological diversity 1988-1992: Gland, Switzerland, International Union for the Conservation of Nature, Technical report.

Perrin, W.F., Heyning, J.E., 1993, Rostral fusion as a criterion of cranial maturity in the common dolphin, Delphinus delphis: Marine Mammal Science, 9, 195-197.

Perrin, W.F., Mitchell, E.D., Mead, J.G., Caldwell, D.K., Caldwell, M.C., Van Bree, P.J.H, Dawbin, W.H., 1987, Revision of the spotted dolphins, Stenella spp.: Marine Mammal Science, 3(2), 99-170.

Pichler, F.B., Robineau, D., Goodall, R.N.P., Meyer, M.A., Olivarría, C., 2001, Origin and radiation of southern hemisphere coastal dolphins (genus Cephalorhynchus): Molecular Ecology, 10, 2215-2223.

Price, S.A., Bininda-Emonds, O.R.P., Gittleman, J.L., 2005, A complete phylogeny of the whales, dolphins and even-toed hoofed mammals (Cetartiodactyla): Biological Reviews, 80, 445-473.

Ramos, R.M.A., Di Beneditto, A.P.M., Lima, N.R.W. 2000. Relationship between dental morphology, sex, body length and age in Pontoporia blainvillei and Sotalia fluviatilis (Cetacea) in Northern Rio de Janeiro, Brazil: Revista Brasileira de Biologia, 60(2), 283-290.

Reinhardt, J., 1862, Om en for den Danske Fauna ny Delphinart (Pseudorca crassidens Owen): Oversigt over det Konglige Danske Videnskabernes Selskabs Forhandlinger, 103-152.

Reyes, J.C., 1996, A possible case of hybridism in wild dolphins: Marine Mammal Science, 12, 301-307.

Rice, D.W., 1967, Cetaceans, in Anderson, S., Jones, J.K. Jr. (eds.), Recent Mammals of the World: A synopsis of families: New York, U.S.A., Ronald Press Co., 291-324.

Rice, D.W., 1998, Marine mammals of the world. Systematics and distribution. Special Publication No.4: The Society for Marine Mammalogy, Allen Press, 1-231.

Riddle, B.R., Hafner, D.J., Alexander, L.F., Jaeger, J.R., 2000, Cryptic vicariance in the historical assembly of a Baja California peninsular desert biota: Proceedings of the National Academy of Sciences, 97(26), 14438-14443.

Ruiz-Geraldo, G., 2005, Cartografía y estratigrafía de la Cuenca Punta Colorada de la Isla San José, Baja California Sur, Mexico: La Paz, Baja California Sur, México, Universidad Autónoma de Baja California Sur, Bachelor's Thesis.

Simpson, G.G., 1945, The principles of classification and a classification of mammals: Bulletin of the American Museum of Natural History, $85,1-350$

Slijper, E.J., 1936, Die Cetaceen. Vergleichend-anatomisch und systematisch: Capita Zoologica, 6, i-xv, 1-590. 
Swofford, D.L., 2002, PAUP*. Phylogenetic Analysis Using Parsimony (* and Other Methods). Version 4. Sinauer Associates, Sunderland, Massachusetts.

Sylvestre, J.P., Tasaka, S., 1985, On the intergeneric hybrids in cetaceans: Aquatic Mammals, 11(3), 101-108.

Thomas, H.W., Barnes, L.G., 1993, Discoveries of fossil whales in the Imperial Formation, Riverside County, California, and the northern extent of the Proto-Gulf of California, in Reynolds, R.E., Reynolds, J. (eds.), Ashes, faults and basins: San Bernardino, California, U.S.A., San Bernardino County Museum Association, Special Publication 93(1), 34-36.

Tomilin, A.G., 1957, Vol. IX Cetacea, in Heptner, V.G. (ed.), Mammals of the U.S.S.R. and Adjacent Countries: U.S.S.R., Izdatel'stvo Akademi Nauk, 1-717.

Umhoefer, P.J., Schwennicke, T., Del Margo, M.T., Ruiz-Geraldo, G., Ingle, J.C., McIntosh, W., 2007, Transtensional fault-termination basins: an important basin type illustrated by the Pliocene San Jose Island basin and related basins in the southern Gulf of California, Mexico: Basin Research, 1-26.

Watson, L., 1981, Sea guide to whales of the world: New York, E.P. Dutton, 1-302.

Werth, A.J., 1992, Anatomy and evolution of odontocete suction feeding: Cambridge, Massachusetts, Harvard University, Doctoral Thesis.
Werth, A.J., 2006a, Mandibular and dental variation and the evolution of suction feeding in Odontoceti: Journal of Mammalogy, 87(3), $579-588$.

Werth, A.J., 2006b, Odontocete suction feeding: experimental analysis of water flow and head shape: Journal of Morphology, 267, 1415-1428.

Winge, H., 1918, Udsigt over Hvalernes indbyrdes Slægtskab: Videnskabelige Meddelelser fra Dansk Naturhistorike Forenening, 70, 59-142.

Winge, H., 1921, A review of the interrelationship of the Cetacea: Smithsonian Miscellaneous Collections, 72, 1-97.

Yazdi, P., 2002, A possible hybrid between the dusky dolphin (Lagenorhynchus obscurus) and the southern right whale dolphin (Lissodelphis peronii): Aquatic Mammals, 28(2), 211-217.

Zoertnetzer, H.R., Duffield, D.A., 2003, Captive born bottlenose dolphin $\mathrm{x}$ common dolphin (Tursiops truncatus $\mathrm{x}$ Delphinus capensis) intergeneric hybrids: Canadian Journal of Zoology, 81, 1755-1762.

Manuscript received: February 27, 2009.

Corrected manuscript received: June 18, 2009.

Manuscript accepted: June 22, 2009. 